ORNL/TM-2001/169

\title{
Assessment of On-Site Power Opportunities in the Industrial Sector
}

September 2001

Prepared by:

Onsite Energy Corporation

Under contract No. 85X-TA008V

701 Palomar Airport Road, Suite 200

Carlsbad, California 92009

Teresa Bryson

William Major

Ken Darrow 



\title{
ASSESSMENT OF ON-SITE POWER OPPORTUNITIES IN THE INDUSTRIAL SECTOR
}

\author{
Energy Division
}

September 2001

\author{
Prepared by \\ OAK RIDGE NATIONAL LABORATORY \\ P.O. Box 2008 \\ Oak Ridge, Tennessee 37831-6285 \\ managed by UT-Battelle, LLC \\ for the \\ U.S. DEPARTMENT OF ENERGY \\ under contract DE-AC-00OR22725
}





\section{TABLE OF CONTENTS}

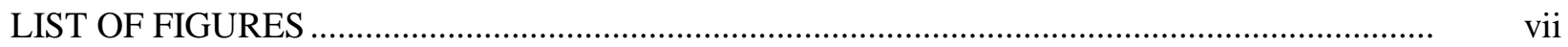

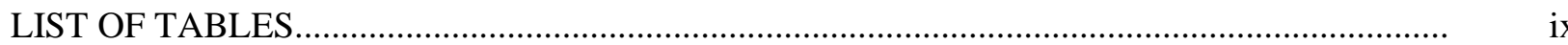

ACRONYMS.

ix

ACKNOWLEDGMENTS.

xiii

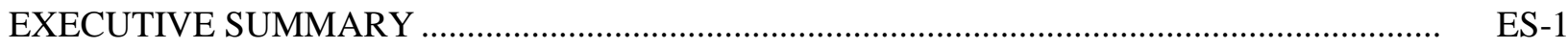

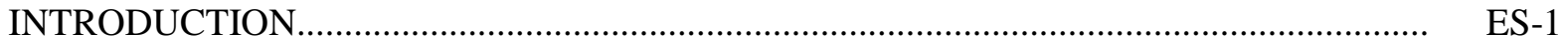

EXISTING ON-SITE GENERATION IN THE INDUSTRIAL SECTOR .............................. ES-1

REMAINING POTENTIAL FOR ON-SITE GENERATION IN THE

INDUSTRIAL SECTOR .......................................................................................... ES-2

REMAINING CHP POTENTIAL IN THE INDUSTRIAL SECTOR …............................... ES-3

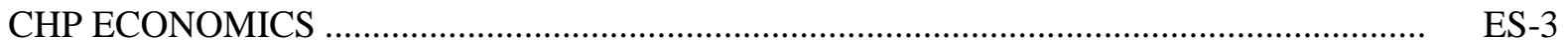

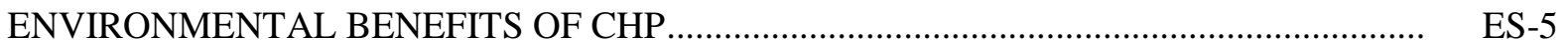

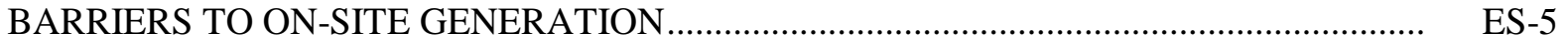

POLICY AND TECHNOLOGY RECOMMENDATIONS ……....................................... ES-5

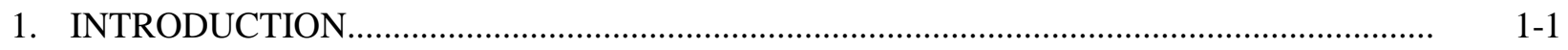

2. ON-SITE GENERATION POTENTIAL IN THE INDUSTRIAL SECTOR .........................

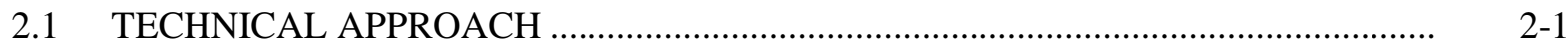

2.1.1 Database of Large Industrial Sites ...............................................................

2.1.2 Database of Small Industrial Sites .................................................................

2.1.3 Database of Operating CHP and Small Power Plants..................................... 2-2

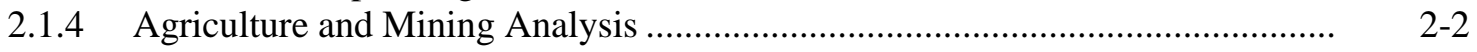

2.2 POWER-ONLY AND CHP TECHNICAL POTENTIAL .......................................... $2-2$

2.3 MECHANICAL DRIVE MARKET ................................................................... 2-

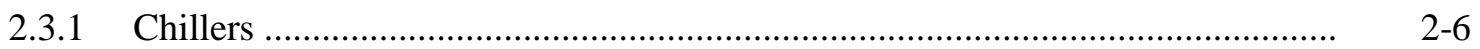

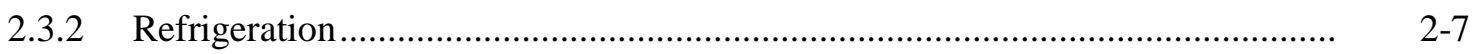

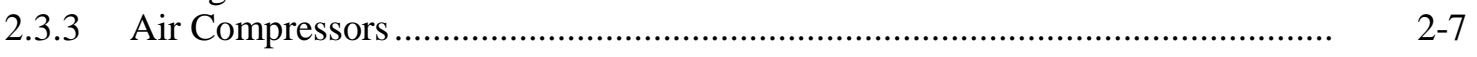

2.3.4 Sales of Selected Industrial Prime Movers .................................................... $2-7$

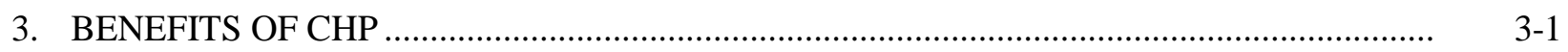

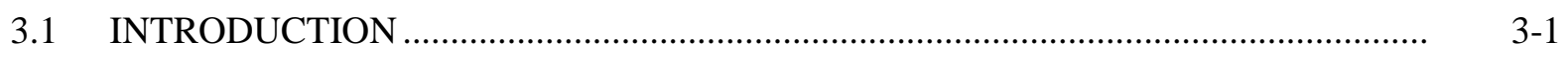

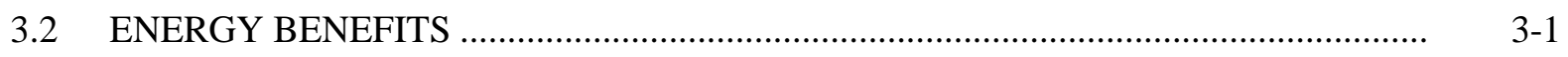

3.3 ENVIRONMENTAL BENEFITS AND EMISSIONS REDUCTION ......................... $3-2$

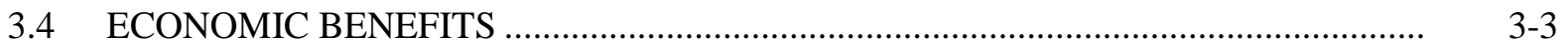

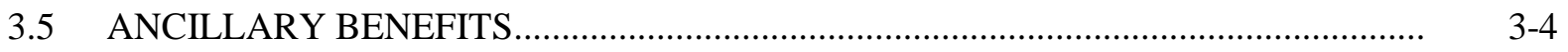

3.6 BENEFITS CALCULATION FOR EXISTING AND POTENTIAL

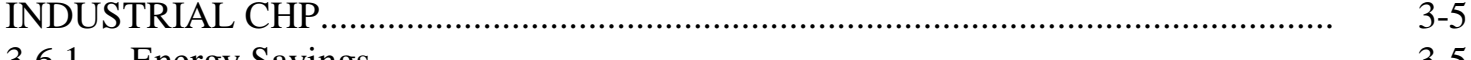

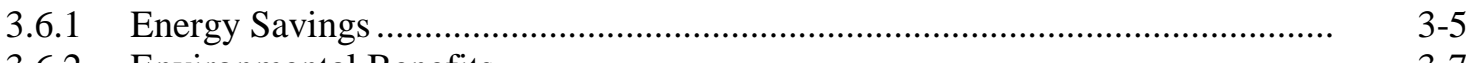

3.6.2 Environmental Benefits .......................................................................... $3-7$

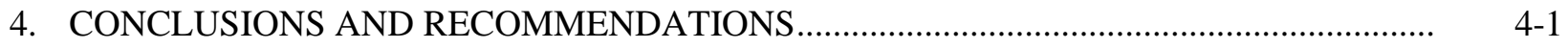

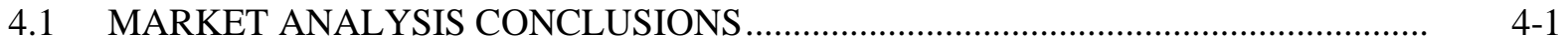

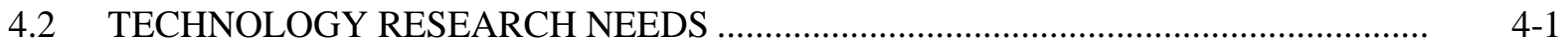

4.3 MARKET AND REGULATORY NEEDS .............................................................. 
$4.4 \quad$ INDUSTRY SPECIFIC INITIATIVES.................................................................

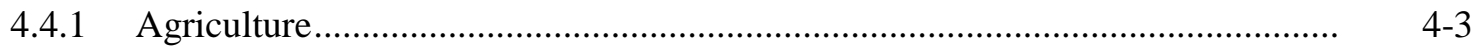

4.4.2 Food Processing ............................................................................................... 4-3

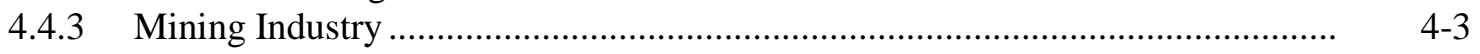

4.4.4 Forest Products Industry ………………………………………………….. 4-3

4.4.5 Chemical Industry...................................................................................... 4.

4.4.6 Petroleum Refining Industry......................................................................... 4.. 4

4.4.7 Glass Industry …………………………………………………....

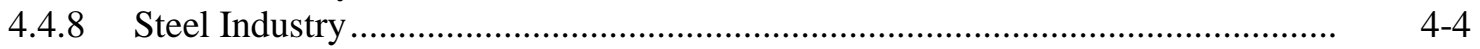

4.4.9 Aluminum Industry................................................................................ 4

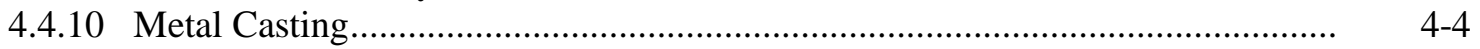

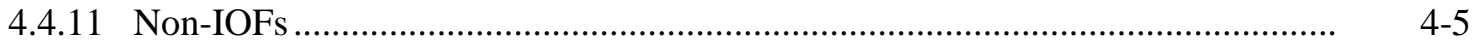

5. BIBLIOGRAPHY ………………………………………………………………..

APPENDIX A: ENERGY USE IN THE IOFs ......................................................................... A- A

A.1 IMPORTANCE OF THE IOFs TO THE U.S. ECONOMY ......................................... A- A-1

A.2 AGRICULTURE ……………………………………………………………. A

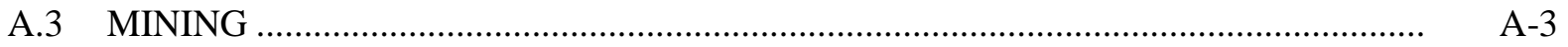

A.4 FOOD PROCESSING ……………………………………………………. A- A

A.5 FOREST PRODUCTS ……………………………………………………..... A-4

A.6 CHEMICALS …………………………………………………………... A-4

A.7 PETROLEUM REFINING ............................................................................ A

A.8 GLASS INDUSTRY ………………………………………………………... A

A.9 ALUMINUM INDUSTRY ................................................................................. A-6

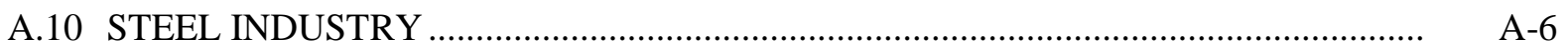

A.11 METALS CASTING ......................................................................................... A-7

A.12 ENERGY USE IN THE IOFs............................................................................... A-7

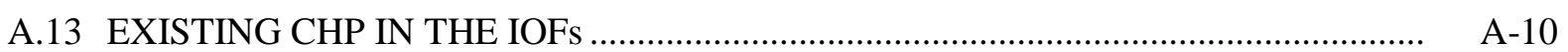

APPENDIX B: IMPACT OF ELECTRIC INDUSTRY RESTRUCTURING ON THE IOFs .......... $\quad$ B-1

B.1 IMPACTS OF RESTRUCTURING ON INDUSTRY ……………………………….... B

B.1.1 Regional Price Variability ............................................................................ B-1

B.1.2 Customer Class Variability ........................................................................ B-2

B.1.3 Noncompetitive Assets .................................................................................. B-2

B.2 A NEW ROLE FOR ON-SITE GENERATION ………….......................................... B-3

B.2.1 Combined Heat and Power ............................................................................ B B-3

B.2.2 Standby Power................................................................................ B-4

B.2.3 Peak-Shaving ......................................................................................... B-. B-4

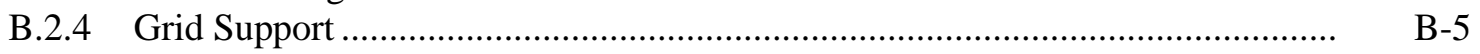

B.2.5 Stand Alone (Grid Isolated) ........................................................................ B B-6

APPENDIX C: ON-SITE GENERATION TECHNOLOGIES …………………………………..... C C $\quad$ -

C.1 ON-SITE GENERATION TECHNOLOGIES ........................................................ C-1

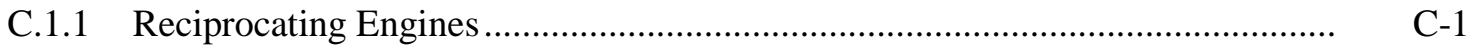

C.1.2 Steam Turbines ……………………………………………………... C-1

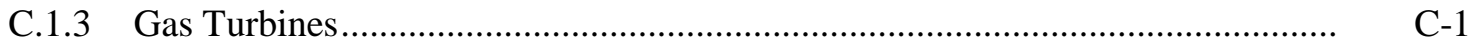

C.1.4 Microturbines.................................................................................. C-3

C.1.5 Fuel Cells ..................................................................................... C-3

C.2 SYSTEM ISSUES ……………………………………………………..... C-3

C.2.1 Electric and Thermal Load Profiles ................................................................. C- C-3 
C.2.2 Quality of Recoverable Heat …........................................................... C-5

C.2.3 Reliability Needs ........................................................................ C-5

C.2.4 Power Quality ................................................................................. C-5

C.2.5 Industrial Heat Recovery ..................................................................... C-6

C.2.6 Environmental Requirements ................................................................. C-6

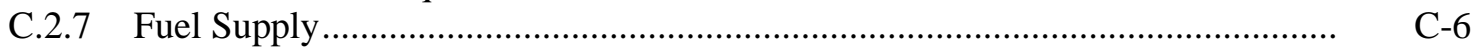

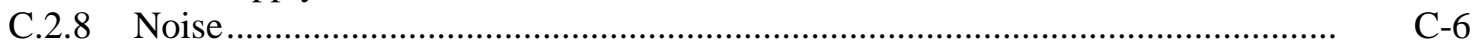





\section{LIST OF FIGURES}

ES.1 Existing CHP in the industrial sector ...................................................................... ES-2

ES.2 In-fence on-site generation potential for industry …................................................. ES-2

ES.3 Remaining CHP potential for the industrial sector ..................................................... ES-3

ES.4 Comparison of CHP net power costs to U.S. industrial electricity prices .......................... ES-4

ES.5 Effect of CHP fuel price on industrial market share .......................................................... ES-4

ES.6 Global warming implications of CHP …............................................................ ES-5

$2.1 \quad$ Methodology for estimating remaining CHP potential ........................................... $2-1$

$2.2 \quad$ Remaining CHP potential sorted by capacity ......................................................... $2-3$

2.3 Existing and remaining CHP potential sorted by industry ............................................

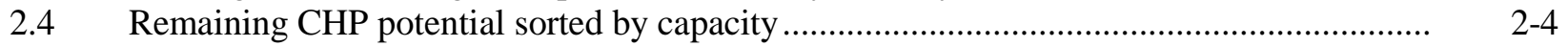

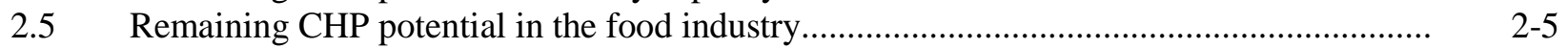

2.6 Remaining CHP potential in the paper industry ............................................................

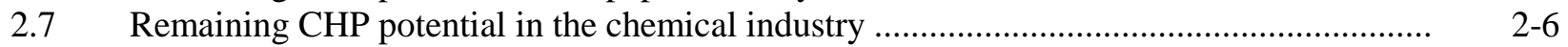

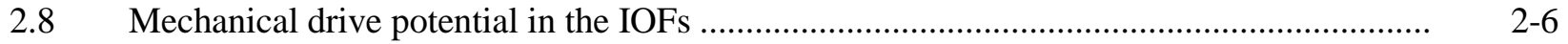

2.9 Refrigeration applications sorted by compressor capacity ......................................... $2-7$

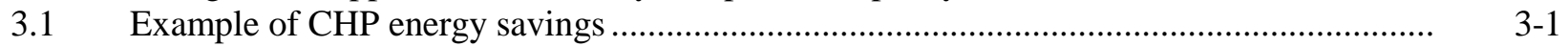

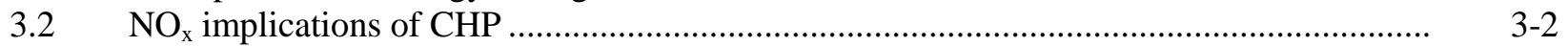

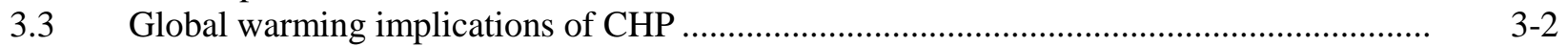

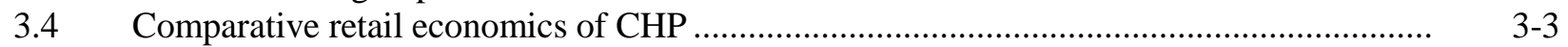

3.5 CHP competitive industrial market shares .................................................................

3.6 Effect of CHP fuel price on competitive industrial market share ...................................... 3-4

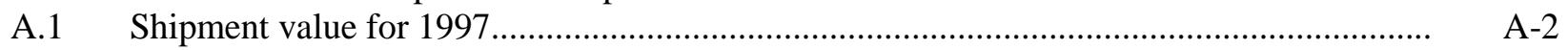

A.2 Total energy consumption .................................................................... A- A

A.3 Energy intensity for selected activities ................................................................. A-9

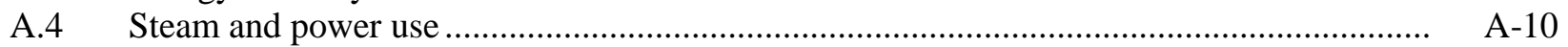

A.5 Existing CHP capacity ....................................................................................... A A 11

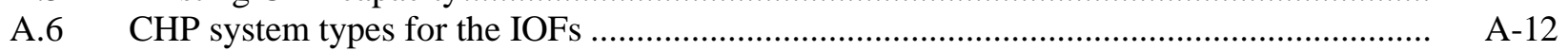

B.1 Regional variation in average industrial electricity prices ......................................... B-1 



\section{LIST OF TABLES}

2.1 Remaining power-only and CHP potential ............................................................ $2-3$

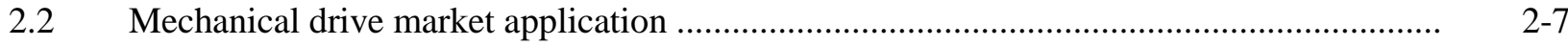

3.1 Representative CHP cost and performance …................................................................ $3-5$

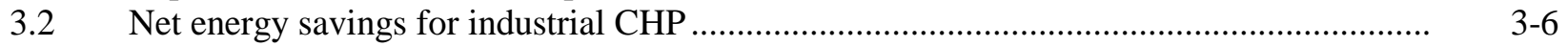

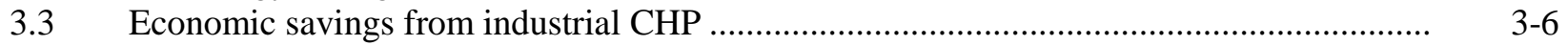

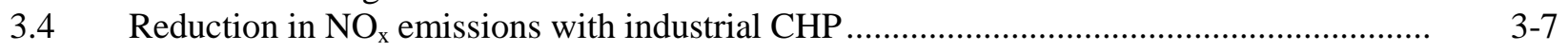

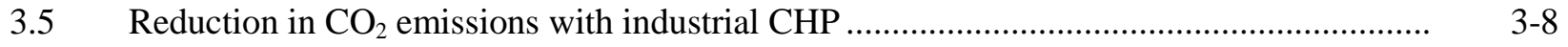

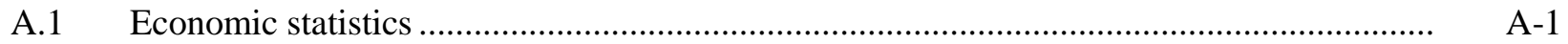

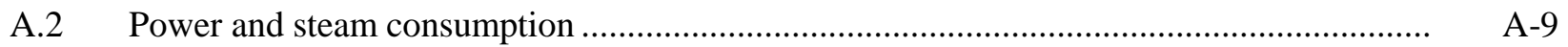

A.3 Components of net electrical requirements ................................................................... A-10

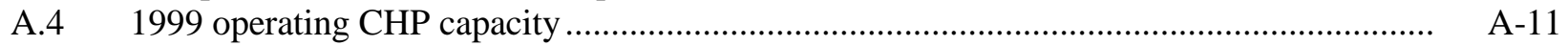

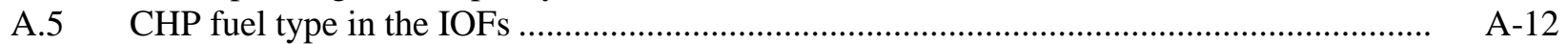

C.1 Comparison of on-site generation technologies ...................................................... C-2 



\section{ACRONYMS}

$\begin{array}{ll}\text { CHP } & \text { combined heat and power } \\ \text { DG } & \text { distributed generation } \\ \text { DOE } & \text { U.S. Department of Energy } \\ \text { EPACT92 } & \text { Energy Policy Act of 1992 } \\ \text { HRSG } & \text { heat recovery steam generator } \\ \text { HVAC } & \text { heating, ventilation, and air conditioning } \\ \text { IOFs } & \text { Industries of the Future } \\ \text { MECS } & \text { Manufacturing Energy Consumption Survey } \\ \text { MIPD } & \text { Major Industrial Plant Database } \\ \text { O\&M } & \text { operation and maintenance } \\ \text { OEC } & \text { Onsite Energy Corporation } \\ \text { OIT } & \text { Office of Industrial Technologies } \\ \text { P/S } & \text { power-to-steam } \\ \text { PURPA } & \text { Regulatory Policy Act of 1978 } \\ \text { SIC } & \text { Standard Industrial Classification } \\ \text { T\&D } & \text { transmission and distribution } \\ \text { TOU } & \text { time-of-use } \\ \text { UPS } & \text { uninterruptible power systems }\end{array}$





\section{ACKNOWLEDGMENTS}

This report was prepared by Onsite Energy Corporation (OEC), under contract with Oak Ridge National Laboratory sponsored by the U.S. Department of Energy's Office of Industrial Technology. The information and results contained in this work are preliminary.

The authors would like to acknowledge the participation and guidance of the following individuals whose assistance and direction was greatly appreciated: William Parks, Patricia Hoffman, and Debbie Haught of the U.S. Department of Energy and Mike Karnitz and Therese Stovall of Oak Ridge National Laboratories. 



\section{EXECUTIVE SUMMARY}

\section{INTRODUCTION}

The purpose of this report is to identify the potential for on-site power generation in the U.S. industrial sector with emphasis on nine industrial groups called the "Industries of the Future" (IOFs) by the U.S. Department of Energy (DOE). Through its Office of Industrial Technologies (OIT), the DOE has teamed with the IOFs to develop collaborative strategies for improving productivity, global competitiveness, energy usage and environmental performance. Total purchases for electricity and steam for the IOFs are in excess of $\$ 27$ billion annually. Energy-related costs are very significant for these industries. The nine industrial groups are

1. Agriculture (SIC 1)

2. Forest products

3. Lumber and wood products (SIC 24)

4. Paper and allied products (SIC 26)

5. Mining (SIC 11, 12, 14)

6. Glass (SIC 32)

7. Petroleum (SIC 29)

8. Chemicals (SIC 28)

9. Metals (SIC 33)

- Steel

- Aluminum

- Metal casting

Although not currently part of the IOF program, the food industry is included in this report because of its close relationship to the agricultural industry and its success with on-site power generation.

On-site generation provides an alternative means to reduce energy costs, comply with environmental regulations, and ensure a reliable power supply. On-site generation can ease congestion in the local utility's electric grid. Electric market restructuring is exacerbating the price premium for peak electricity use and for reliability, creating considerable market interest in on-site generation.

\section{EXISTING ON-SITE GENERATION IN THE INDUSTRIAL SECTOR}

On-site power generation is not a new concept for the U.S. industrial sector. Historically, the on-site power market was driven by the availability of waste fuels, locally high retail electricity prices, and attractive wholesale power purchase agreements. Existing on-site generation capacity in the industrial sector, exclusive of emergency generator sets, is in excess of 45,000 MW with a vast majority $(42,000 \mathrm{MW})$ being combined heat and power (CHP) plants. The IOFs account for $93 \%$ of this installed capacity as shown in Fig. ES.1.

A high percentage of applications employing large on-site power plants have already been implemented as CHP and dominate the installed capacity shown in Fig. ES.1. Much of the remaining potential can be characterized as smaller discrete loads, mechanical drive applications providing chilled water, and liquids pumping and facilities with smaller electric and/or thermal loads. 


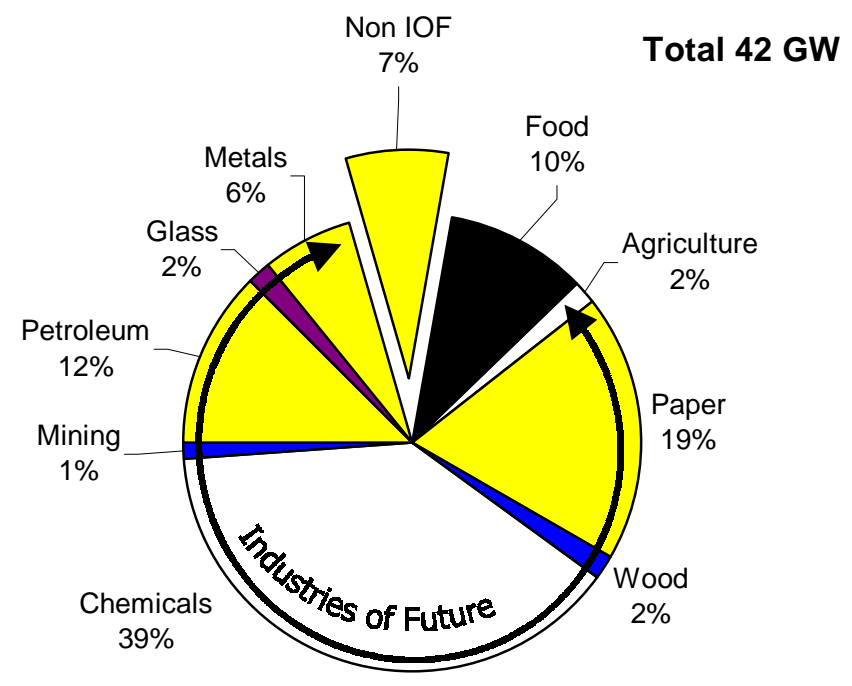

Fig. ES.1. Existing CHP in the industrial sector.

\section{REMAINING POTENTIAL FOR ON-SITE GENERATION IN THE INDUSTRIAL SECTOR}

The total remaining potential for in-fence, on-site generation in the industrial sector is estimated at 140,000 MW. This potential represents the total site (in-fence) electric demand for power only and CHP. The IOFs represent approximately 113,000 MW, or 79\% of the total opportunity, as shown in Fig. ES. 2.

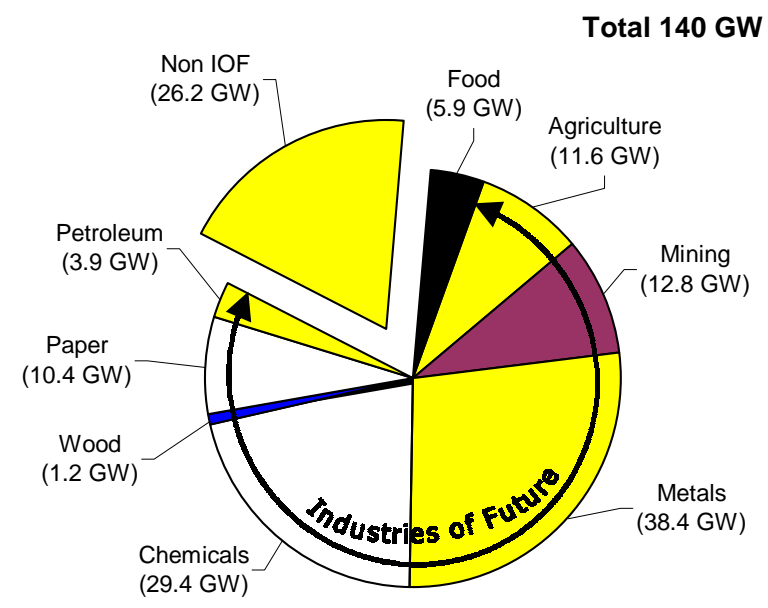

Fig. ES. 2. In-fence, on-site generation potential for industry. 


\section{REMAINING CHP POTENTIAL IN THE INDUSTRIAL SECTOR}

The remaining CHP potential in the industrial sector is estimated at $88,000 \mathrm{MW}$. Remaining potential for the IOF industry groups is estimated at $61,000 \mathrm{MW}$, or $69 \%$ of the total CHP opportunity, as shown in Fig. ES. 3. The CHP potential includes systems that export power to the grid, meaning that the estimated potentials are in excess of site (in-fence) demand requirements.

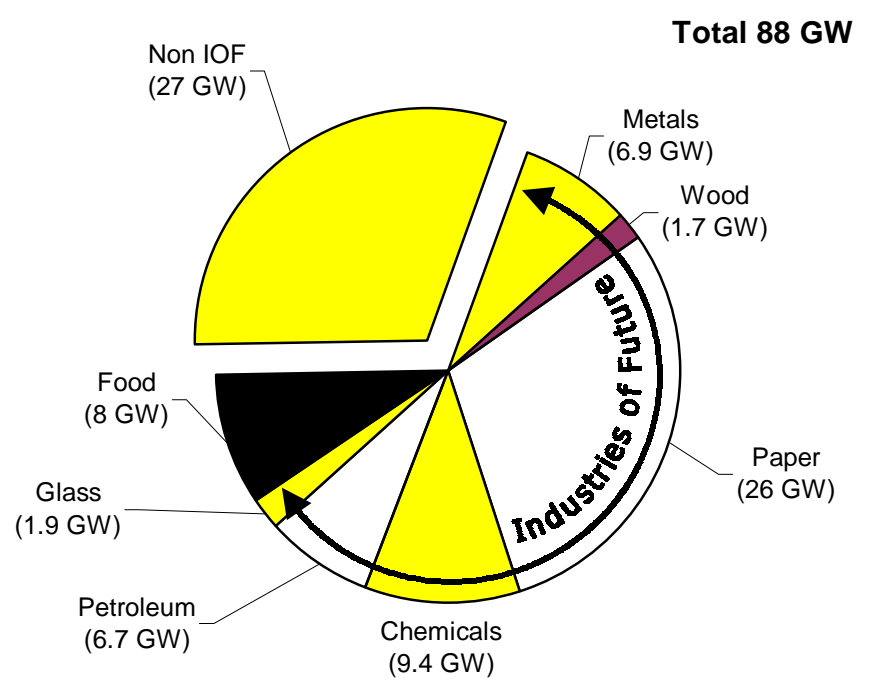

Fig. ES.3. Remaining CHP potential for the industrial sector.

\section{CHP ECONOMICS}

The economics of CHP can be compelling when compared to industrial electric rates. Fig. ES.4 indicates the price points for several CHP technologies as compared to the U.S. industrial electricity price distribution. The figure shows that a 5-MW CHP system is competitive with delivered electricity prices for $37 \%$ of industrial customers. For a 30-MW system, the comparison shows that CHP is competitive for $68 \%$ of industrial customers. A 1-MW reciprocating engine system is competitive in $20 \%$ of the industrial sector. The comparison is based on $\$ 3.50 / \mathrm{MMBtu}$ natural gas cost for the CHP system and the avoided boiler fuel.

The competitive market shares are sensitive to the CHP fuel price. Figure ES.5 shows declining industrial market share for each CHP system as natural gas prices increase. For example, with natural gas at \$2.50/MMBtu, a 30-MW CHP system is competitive in 90\% of the industrial market; however, at $\$ 4.75 / \mathrm{MMBtu}$, the competitive share drops to $43 \%$ of industrial customers, assuming that electric prices remain constant. 


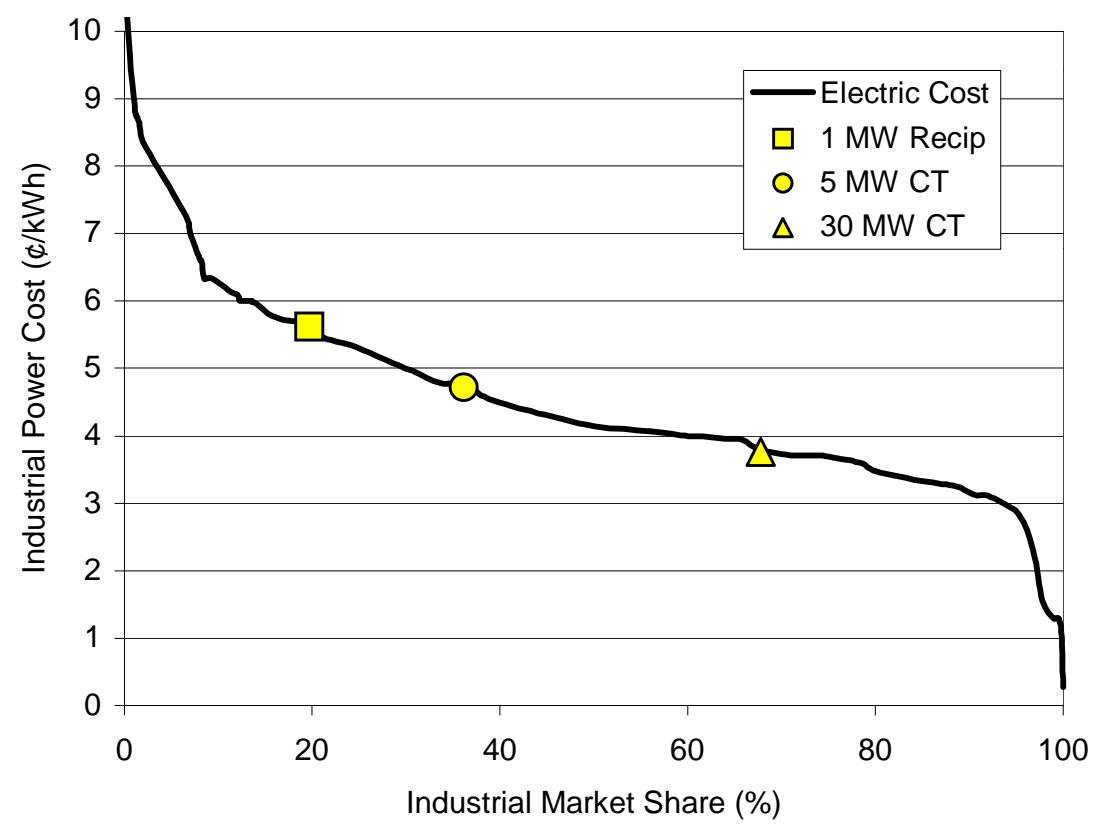

Fig. ES.4. Comparison of CHP net power cost to U.S. industrial electricity prices.

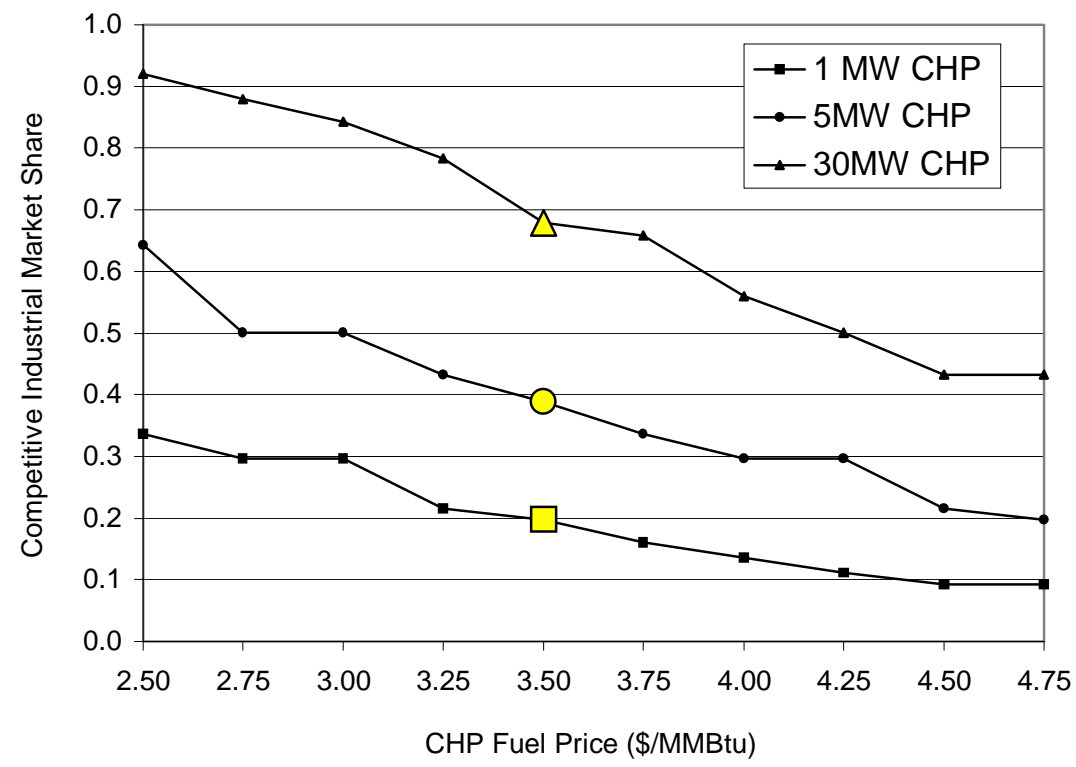

Fig. ES.5. Effect of CHP fuel price on industrial market share. 


\section{ENVIRONMENTAL BENEFITS OF CHP}

The environmental value of CHP is most noteworthy for its potential to reduce global climate change emissions as illustrated in Fig. ES.6. If the full potential for CHP were realized (about $130 \mathrm{GW}$ ), a 70 million metric ton reduction in carbon equivalent emissions would result. This is equivalent to approximately 285 million tons of $\mathrm{CO}_{2}$ emissions.

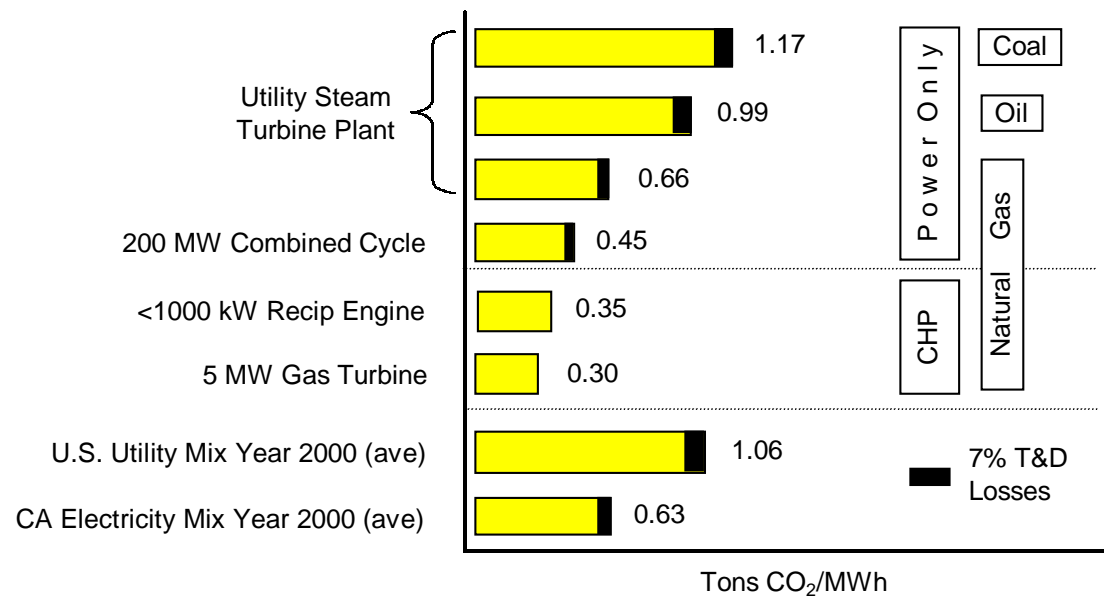

Fig. ES.6. Global warming implications of CHP.

\section{BARRIERS TO ON-SITE GENERATION}

Barriers to on-site generation in the industrial sector have included institutional, market and technical issues such as

- high electric utility backup power costs, onerous grid interconnection requirements, and deferral rates;

- local environmental regulations that do not recognize the offsetting plant boiler and central station generation emissions;

- unfavorable depreciation tax treatment core investment, requiring quick pay-back; and

- high costs for equipment, installation, environmental compliance, and maintenance for smaller on-site generation systems.

\section{POLICY AND TECHNOLOGY RECOMMENDATIONS}

Several regulatory and environmental policies if enacted would benefit on-site generation projects. The following recommendations would level the competitive playing field and accelerate implementation of on-site generation in the U.S. industrial sector.

\section{Regulations}

- propose changes to regulations such that utilities are not disadvantaged by on-site generation and are rewarded for efficient operation of the grid by employing on-site generation and energy efficiency, 
- energy-use based tariffs for standby/backup service with recognition for diversity among on-site generation,

- compensation to on-site generators providing measurable benefits to the transmission and distribution (T\&D) grid, and

- standardized grid interconnect guidelines and "fast track" approval processes.

\section{Environmental}

- environmental policies that encourage efficiency and pollution prevention;

- output-based standards that recognize overall efficiency by crediting heat recovery;

- emission offsets for displaced boiler and central station generation plant emissions;

- incentives to encourage global climate change mitigation through efficiency improvements and CHP; and

- information, education, and training programs to enhance industry awareness and capabilities.

\section{Tax Treatment}

- shorter depreciation schedules or tax credits to reflect the true life of the investment and risk profile

\section{Government Support for Smaller Generation Technologies ( $<20$ MW)}

- improve controls for process integration,

- improve controls and communication systems for grid interconnection,

- value recognition of grid support,

- support and promote integration of on-site generation into processes and facilities,

- improve efficiency and reduce emissions for reciprocating engines and micro-turbines,

- demonstrate mechanical drive applications, and

- develop and demonstrate process cooling applications utilizing recovered heat from CHP systems. 


\section{INTRODUCTION}

The DOE Office of Industrial Technologies (OIT) has allocated resources to assist nine key U.S. industries to improve their productivity through more efficient and cost-effective energy use. These industries have created an alliance with OIT referred to as the "Industries of the Future" (IOFs) and include membership in the following areas:

1. Agriculture (SIC 1)

2. Forest Products

3. Lumber and Wood Products (SIC 24)

4. Paper and Allied Products (SIC 26)

5. Mining (SIC 11, 12, 14)

6. Glass (SIC 32)

7. Petroleum (SIC 29)

8. Chemicals (SIC 28)

9. Metals (SIC 33)

- Steel

- Aluminum

- Metal Casting

The IOFs are developing strategies (road maps) to improve their bottom line by addressing productivity, global competitiveness, energy usage, markets, and environmental performance.

One strategy to control energy costs that many industrial facilities have successfully employed is on-site power generation. When coupled with waste heat recovery, the system is referred to as combined heat and power $(\mathrm{CHP})^{*}$. On-site power generation allows industry to use the waste heat that central power stations typically must discharge to the environment. CHP can reduce energy costs and increase productivity. From a national perspective, CHP reduces U.S. consumption of energy and decreases regional air emissions and greenhouse gases that contribute to global warming. "Power-only" on-site generation (without heat recovery) also provides benefits by reducing the facility's peak power costs, deferring the need for power system expansion, increasing reliability for the facility and the grid, and improving power quality. On-site generation systems, whether CHP or power-only, are further referred to as distributed generation (DG) to distinguish them from traditional central station power plants.

Under contract with OIT, Onsite Energy Corporation (OEC) examined the current status and future outlook for on-site generation and other selected industrial applications in the IOFs. This report addresses the current use of CHP in the industrial sector, the remaining potential for CHP and other remaining onsite generation opportunities, and the development of initiatives that will impact deployment of such systems in the future. In addition to the IOFs, the food-processing sector has been included in this analysis based on previous work conducted for OIT. The report is organized into the following sections:

- On-Site Generation Potential in the Industry Sector-This section presents the remaining potential for CHP and power-only generation in the industrial sector.

\footnotetext{
* Combined heat and power systems are also known as cogeneration systems. The term cogeneration has become strongly associated with a particular regulatory process and contracting approach that was imposed on utilities in 1978 by federal and state regulation. The term CHP is now used to distinguish the underlying technology from an outdated regulatory configuration of that technology.
} 
- Benefits of CHP-This section describes the benefits of on-site generation to the IOFs, the electric industry, and to society.

- Conclusions and Recommendations-This section discusses opportunities for on-site generation in the IOFs and identifies barriers that inhibit deployment.

The report also has three appendixes:

- Appendix A. Energy Use in the IOFs-This section discusses energy use in the IOFs and existing CHP.

- Appendix B. Impact of Electric Industry Restructuring on the IOFs-This section summarizes the changes occurring in the electric power industry and the impact on industrial onsite generation. The section also includes case studies and application descriptions of on-site generation in industry.

- Appendix C. On-Site Generation Technologies-This section provides an overview of the technologies that are used for on-site generation. 


\section{ON-SITE GENERATION POTENTIAL IN THE INDUSTRIAL SECTOR}

This section discusses the analysis of the technical potential for power-only and CHP systems in the industrial sector. The analysis is based on 1999 data of power and steam consumption for existing industrial facilities. The analysis assumes that CHP systems generate steam from the recovered heat; no quantitative estimates were made for mechanics or for other uses of thermal energy.

\subsection{TECHNICAL APPROACH}

Three separate databases were used to estimate the remaining industrial on-site generation potential. A schematic of the approach and the databases is shown in Fig. 2.1.

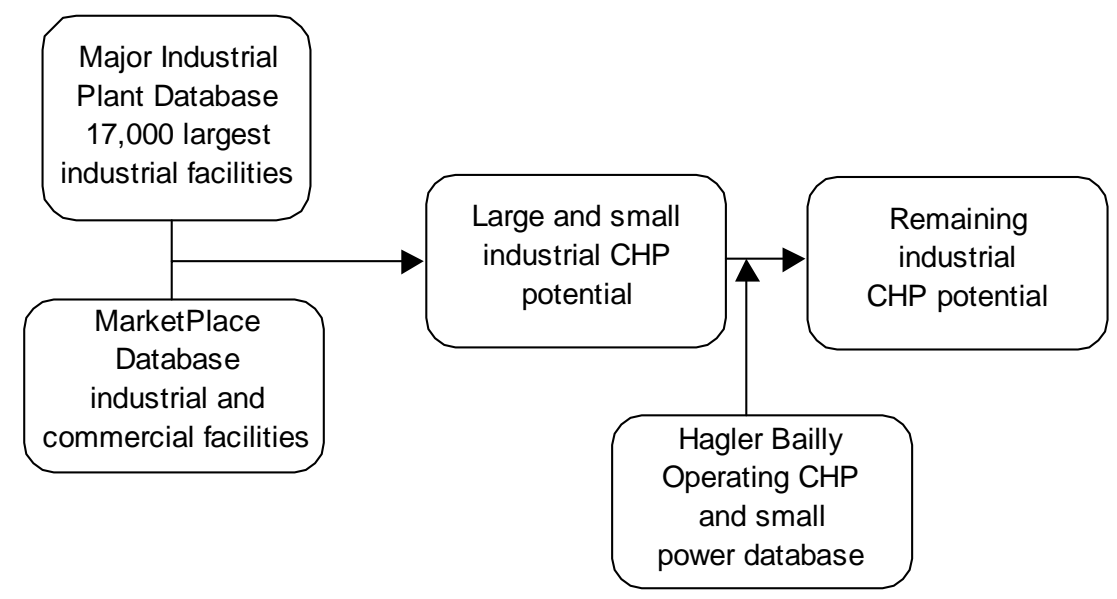

Fig. 2.1. Methodology for estimating remaining CHP potential.

\subsubsection{Database of Large Industrial Sites}

The Major Industrial Plant Database (MIPD) (Petroleum Information/Dwights 1998) contains a detailed description of over 18,000 of the largest industrial facilities in the United States. The MIPD covers approximately 18,000 of the estimated 250,000 manufacturing facilities in the United States. This database was employed to aggregate the electrical capacity and steam use for each site and to sort them by size and power-to-steam (P/S) ratios for each two-digit SIC (20-39) and for selected four-digit SICs.

- $\mathrm{P} / \mathrm{S}<0.4-$ Sites with a ratio of less than 0.4 have a relatively high steam load. The CHP system can be sized either to the steam load with export of excess power or to the on-site electric demand, meeting only part of the on-site steam requirements. For this analysis, we have assumed that the CHP system is sized to the steam load, thereby requiring export of power from the site. A simple cycle gas turbine system with a P/S of 0.6 was selected as a representative CHP technology for these sites.

- $\quad 0.4<\mathrm{P} / \mathrm{S}<1.5$ - Sites with between 0.4 and 1.5 are sized to the steam load and provide only part of the on-site electric requirements. A higher efficiency recuperated gas turbine or combined cycle with a P/S of 1.0 was selected as a representative CHP technology for these sites. 
- $\mathrm{P} / \mathrm{S}>1.5$ - Sites with a ratio of greater than 1.5 are not CHP candidates because their on-site steam load is too small compared compared to their electrical requirements; however, they do represent a potential population of power-only systems.

\subsubsection{Database of Small Industrial Sites}

To estimate remaining on-site generation potential for the small industrial sector, the MarketPlace Database developed by iMarket, Inc. was used to identify sites by SIC code that have average electric loads between 100 and 1,000 kW. Unlike MIPD, this database has limited site operating data. The database presorts facilities into ranges of power use. Because there is no direct steam consumption data, direct computation of $\mathrm{P} / \mathrm{S}$ ratios is not possible. SIC categories having adequate steam loads were selected based on power and steam data profiles contained in DOE's Manufacturing Energy Consumption Survey (MECS) (DOE EIA 1994). To determine CHP potential, a reciprocating engine system with a P/S ratio of 0.8 was selected as a representative CHP technology for these sites.

\subsubsection{Database of Operating CHP and Small Power Plants}

The Hagler-Bailly database of CHP and small power plants was used to identify the number of operating CHP plants in the industrial sector. For each of the industrial SIC categories (20-39), existing CHP capacity was subtracted from the total CHP market to arrive at the remaining CHP potential.

\subsubsection{Agriculture and Mining Analysis}

The analytical approach described above does not apply to the agriculture and mining sectors of the IOF. Remaining CHP potential was estimated by subtracting the existing CHP capacity from estimated demand based on energy consumption. For the agricultural sector, information was obtained from the U.S. Census Bureau. Electric demand in this sector was based on the amount of total farm expenditures.

\subsection{POWER-ONLY AND CHP TECHNICAL POTENTIAL}

Table 2.1 shows remaining power-only (in-fence) and CHP technical potential for the industrial sector. The number of sites screened include 8,900 IOF facilities from MIPD, 18,000 mining establishments and 1.91 million farms from the census data, and over 25,000 IOF sites with $<1 \mathrm{MW}$ from the MarketPlace database.

The estimated remaining CHP technical potential for the industrial sector is approximately 88,000 MW. Based on the Hagler-Bailly Independent Power Database, approximately 45,000 MW is already installed that represents about $33 \%$ of the total CHP market. The paper, chemical, food, primary metals, and refining sectors account for approximately $61,000 \mathrm{MW}$ or $61 \%$ of the remaining CHP potential. Paper has the largest remaining CHP potential of any one sector, accounting for 26,000 MW. However, significant remaining potential exists in other industries such as textiles, rubber and plastics, metals fabrication and equipment-industries that have not aggressively implemented CHP. The CHP potential includes larger systems that export excess power to the grid. Often, the thermal load of an industrial site can support a CHP system with greater electrical capacity than just the site requirements. In these cases, the power-only (in-fence) potential is estimated at approximately 140,000 MW for the industrial sector. The power-only market potential represents the in-fence opportunity.

Figure 2.2 shows CHP technical potential sorted by site capacity requirements. Nearly half of the remaining potential is for installations greater than $50 \mathrm{MW}$. Significant technical potential also exists for 
Table 2.1. Remaining power-only and CHP potential

\begin{tabular}{|c|c|c|c|c|c|c|c|}
\hline \multirow{3}{*}{$\mathrm{SIC}$} & \multirow{3}{*}{ SIC Description } & \multirow{3}{*}{$\begin{array}{r}\text { Power Only } \\
\text { Market } \\
(\mathrm{MW})\end{array}$} & \multicolumn{3}{|c|}{ CHP Market } & \multirow{3}{*}{$\begin{array}{r}\text { Existing } \\
\mathrm{CHP} \\
(\mathrm{MW})\end{array}$} & \multirow{3}{*}{$\begin{array}{r}\text { Remaining } \\
\mathrm{CHP} \\
\text { Potential }^{*} \\
(\mathrm{MW})\end{array}$} \\
\hline & & & \multicolumn{2}{|c|}{$\begin{array}{c}\text { Plant Size } \\
\end{array}$} & \multirow{2}{*}{$\begin{array}{r}\text { Total } \\
(\mathrm{MW})\end{array}$} & & \\
\hline & & & $100-1,000 \mathrm{~kW}$ & $>1,000 \mathrm{~kW}$ & & & \\
\hline \multicolumn{8}{|l|}{ IOF } \\
\hline $1-7$ & Agriculture & 11,462 & n.a. & n.a. & n.a. & 751 & n.a. \\
\hline $11,12,14$ & Mining & 12,844 & n.a. & n.a. & n.a. & 492 & n.a. \\
\hline 20 & Food and Kindred Products & 5,896 & 2,683 & 9,997 & 12,680 & 4,594 & 8,086 \\
\hline 24 & Lumber and Wood Products & 1,171 & 595 & 1,946 & 2,542 & 806 & 1,736 \\
\hline 26 & Paper and Allied Products & 10,459 & 1,168 & 33,584 & 34,751 & 8,553 & 26,198 \\
\hline 28 & Chemicals and Allied Products & 29,364 & 1,780 & 25,352 & 27,132 & 17,692 & 9,440 \\
\hline 29 & Petroleum and Coal Products & 3,949 & 154 & 12,253 & 12,407 & 5,618 & 6,789 \\
\hline 32 & Stone, Clay, Glass, Concrete* & 0 & n.a. & 2,699 & 2,698 & 774 & 1,924 \\
\hline \multirow[t]{2}{*}{33} & Primary Metals Industries* & 38,389 & 294 & 9,520 & 9,814 & 2,873 & 6,941 \\
\hline & IOF Total & 113,534 & 6,674 & 95,350 & 102,025 & 42,153 & 61,115 \\
\hline \multicolumn{8}{|l|}{ Non-IOF } \\
\hline 21 & Tobacco and Allied Products & 77 & 16 & 87 & 103 & 131 & - \\
\hline 22 & Textile Mill Products & 2,576 & 766 & 3,011 & 3,777 & 651 & 3,126 \\
\hline 23 & Apparel Manufacturing & 335 & n.a. & 163 & 163 & 0 & 163 \\
\hline 25 & Furniture & 583 & n.a. & 402 & 401 & 68 & 333 \\
\hline 27 & Printing and Publishing & 685 & n.a. & 404 & 404 & 19 & 385 \\
\hline 30 & Rubber and Misc. Plastics & 2,546 & 2,772 & 1,641 & 4,413 & 787 & 3,626 \\
\hline 31 & Leather and Tanning & 92 & n.a. & 98 & 98 & 0 & 98 \\
\hline 34 & Fabricated Metal Products & 2,558 & 4,050 & 1,676 & 5,726 & 78 & 5,648 \\
\hline 35 & Industrial Machinery and Equip. & 4,095 & 4,787 & 1,598 & 6,385 & 149 & 6,236 \\
\hline 36 & Electrical and Electron. Equip. & 4,958 & n.a. & 987 & 987 & 180 & 807 \\
\hline 37 & Transportation Equipment & 4,884 & 1,169 & 4,243 & 5,412 & 808 & 4,604 \\
\hline 38 & Instruments and Related Prod. & 2,483 & 972 & 590 & 1,562 & 59 & 1,503 \\
\hline \multirow[t]{2}{*}{39} & Miscellaneous Manufacturing & 374 & 784 & 343 & 1,128 & 402 & 726 \\
\hline & Non IOF Total & 26,246 & 15,316 & 15,243 & 30,558 & 3,332 & 27,226 \\
\hline $20-39$ & Total Manufacturing & 139,779 & 21,990 & 1110,593 & 132,583 & 45,485 & 88,369 \\
\hline
\end{tabular}

n.a. = not available.

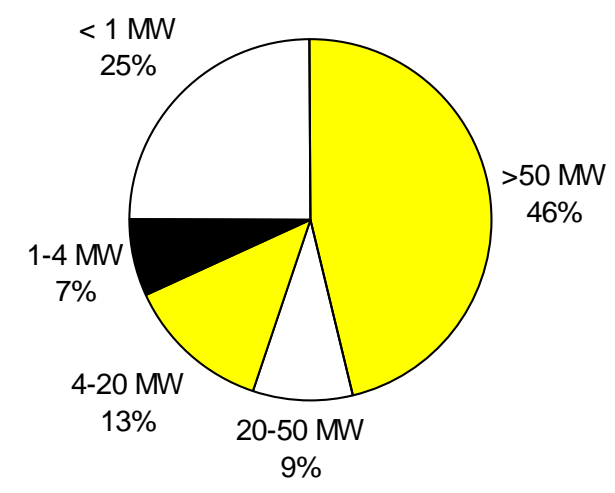

Fig. 2.2. Remaining CHP potential sorted

by capacity. 
sites < $1 \mathrm{MW}$ where there has been little activity because of the high cost of packaging and siting small CHP systems.

Figure 2.3 indicates the capacity of existing and remaining CHP potential for key IOFs. The forest products industry has the largest remaining CHP potential followed by chemicals and food. The chemical industry has demonstrated the highest capacity saturation, having implemented approximately $65 \%$ of its total CHP market. Refining has achieved $45 \%$ saturation. Non-IOFs have installed only $10 \%$ of their potential market.

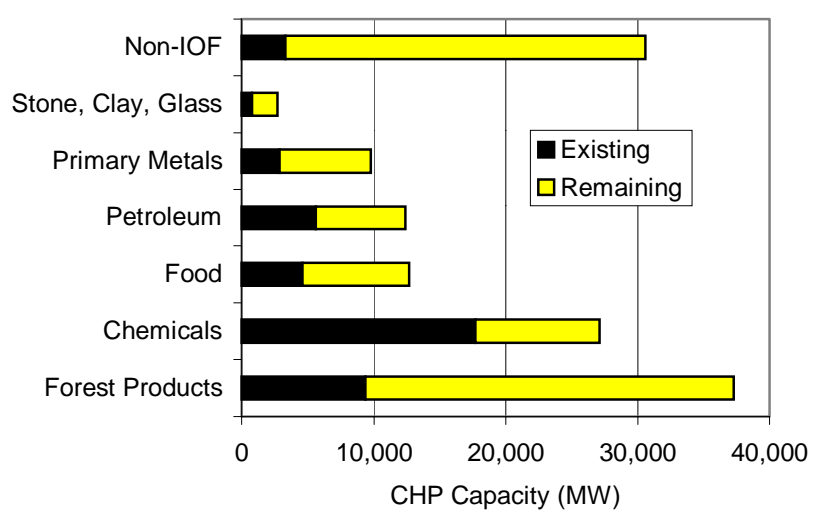

Fig. 2.3. Existing and remaining CHP potential sorted by industry.

Figure 2.4 shows the remaining potential in key industries as a function of site capacity requirements. Applications between 0 and 4 MW will be dominated by reciprocating engines and small industrial gas turbines. Most of the potential for small CHP exists in the food and non-IOF industries. The food, chemical, and non-IOFs contain the largest number of applicable sites in the 4-50 MW size range that is suitable for combustion turbines. The paper industry has the largest share of applicable sites followed by the refining and steel industries for sites having a potential size of $>50 \mathrm{MW}$ and that are suitable for combustion turbines or combined cycle plants. Less potential exists for large CHP in the food and nonIOF sectors. The glass industry has a very low potential for CHP.

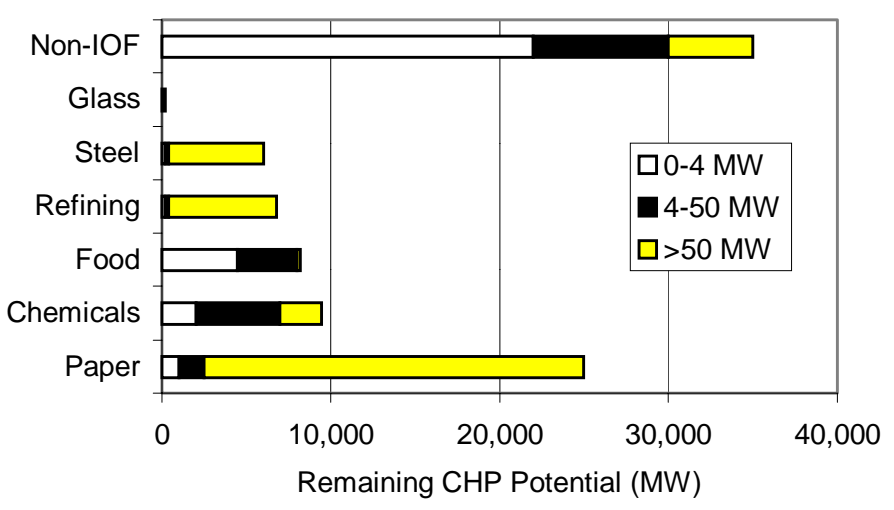

Fig. 2.4. Remaining CHP potential sorted by capacity. 
Figures 2.5 through 2.7 show the remaining CHP potential for selected industries. The highest CHP potentials are in the meat and poultry processing, canned fruits and vegetables, and malt beverages industries. The industries shown do not comprise the entire food industry, and there are opportunities in other sectors. The highest potentials are in the paper and paperboard sectors. In the chemical industry, shown in Fig. 2.7, the highest CHP potentials are in the basic organic and inorganic chemicals sectors. Chlor-alkali production and nitrogenous fertilizers also represent important sectors within the chemical industry.

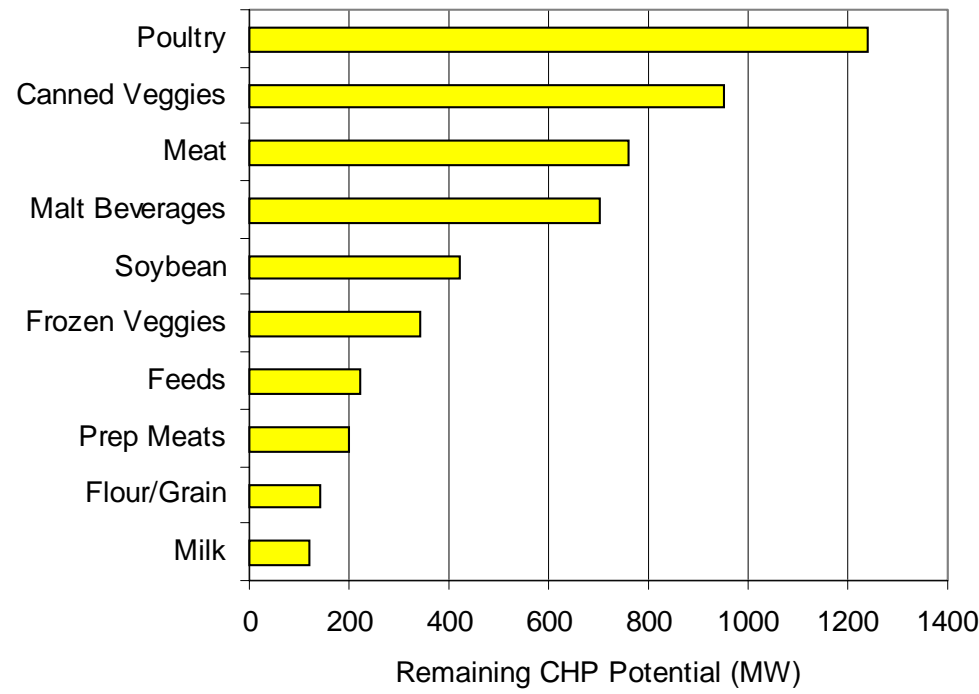

Fig. 2.5. Remaining CHP potential in the food industry.

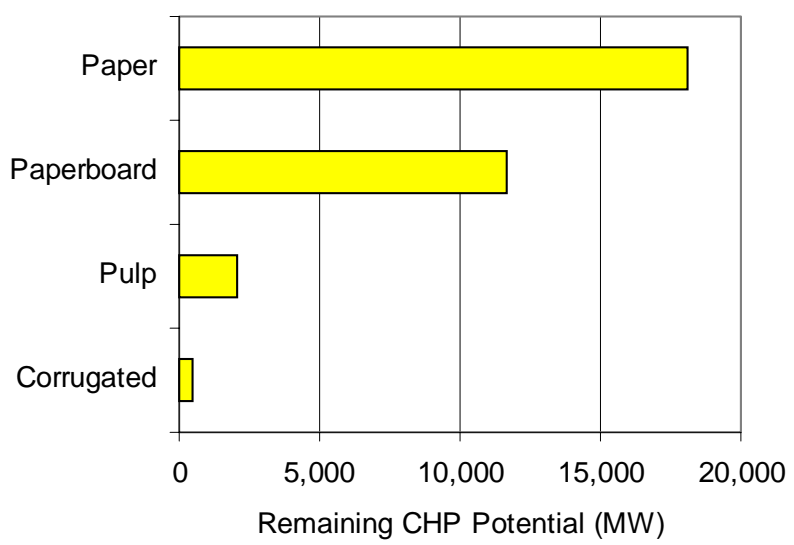

Fig. 2.6. Remaining CHP potential in the paper industry. 


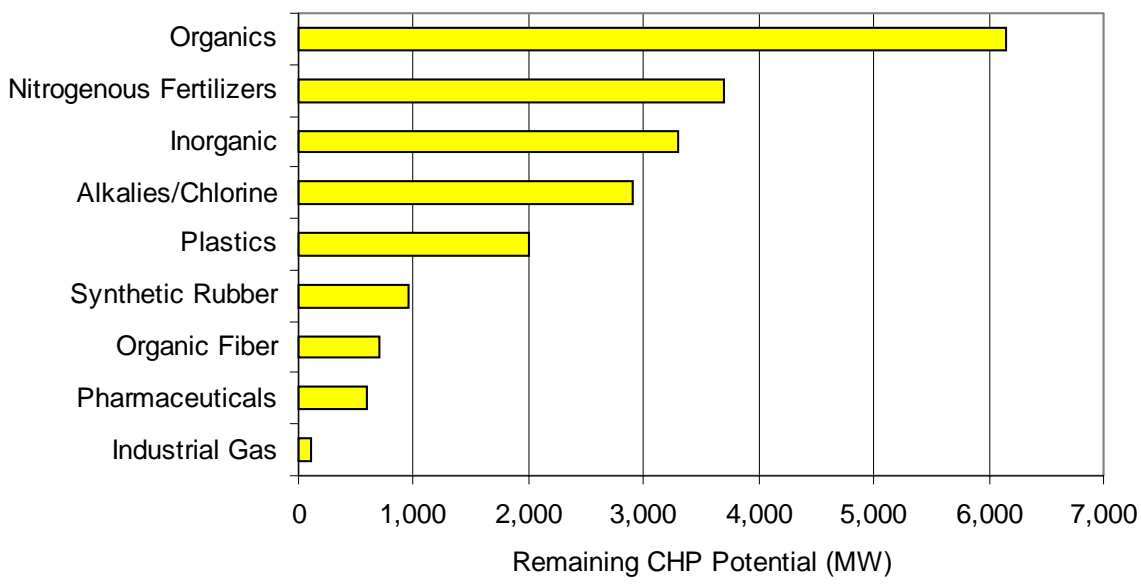

Fig. 2.7. Remaining CHP potential in the chemical industry.

\subsection{MECHANICAL DRIVE MARKET}

In addition to power generation, CHP technologies are used as a prime mover to directly drive equipment such as chillers, refrigeration equipment, air compressors, irrigation, and pumping systems. Significant market potential exists for engine-driven applications in the industrial sector. The current electric use in the IOFs exceeds $90 \mathrm{GW}$ for potential engine-driven applications as shown in Fig. 2.8.

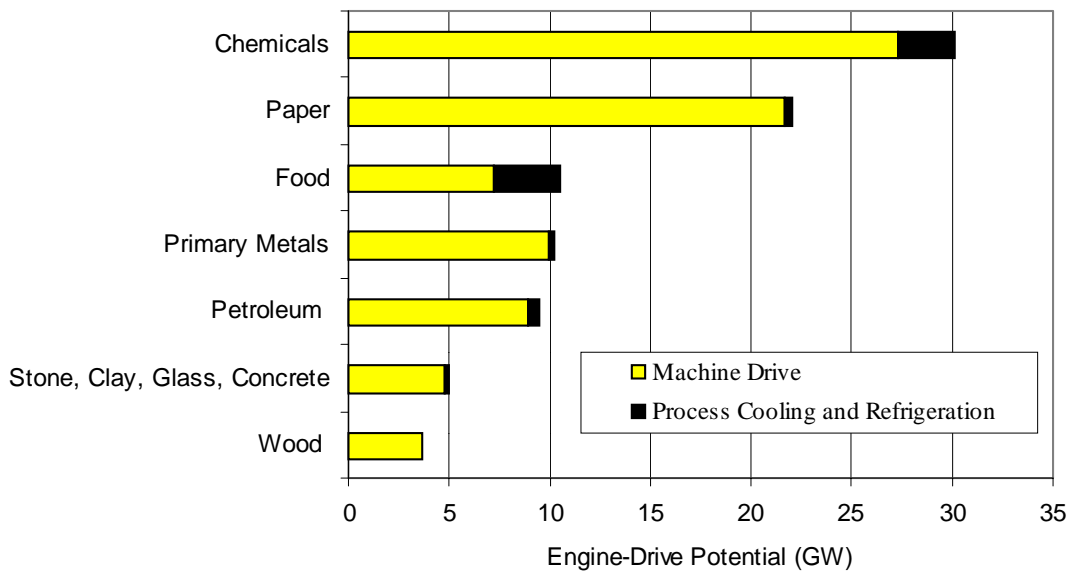

Fig. 2.8. Mechanical drive potential in the IOFs.

\subsubsection{Chillers}

Manufacturing industries used 217 trillion Btu of electricity for HVAC in 1994, accounting for about 8\% of total manufacturing electricity use. A reciprocating engine-driven chiller is a means to reduce peak electrical demand in a facility by replacing electric chillers or other air- conditioning equipment. Overall energy costs are reduced by lowering electrical demand costs. Engine-driven systems also provide good part-load performance as compared to an electric motor drive. Recovery of engine jacket and exhaust heat can supplement process heating or increase the system's cooling capacity with an absorption chiller. 


\subsubsection{Refrigeration}

Refrigeration equipment is a major consumer of energy for industrial process cooling and dehumidification. The engine-driven refrigeration market is growing, promising lower operating costs and enhanced reliability. Engine-driven systems are often used for capacity expansions, particularly when expensive transformer upgrades may be required. The longer operating hours of refrigeration applications improves the economics for engine-driven equipment, especially when heat recovery is employed. Figure 2.9 shows refrigeration applications in subsectors of the food industry for small and large capacity refrigeration compressors. Primary applications include dairies, food processing, meatpacking, and refrigerated warehouses. Total installed refrigeration capacity is estimated between 3 and 4 millions tons.
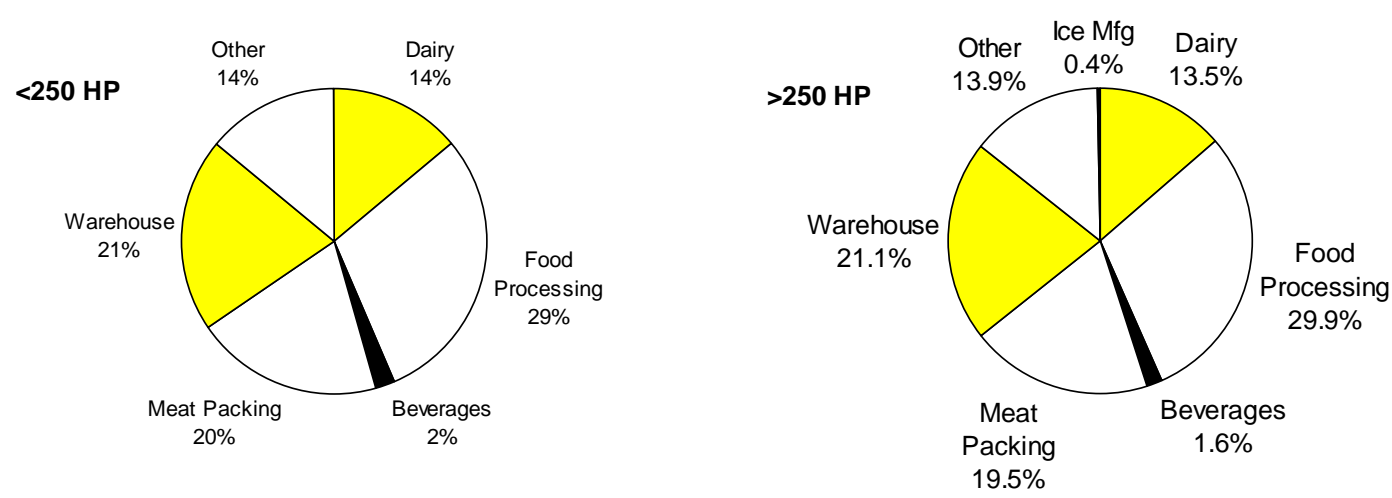

Fig. 2.9. Refrigeration applications sorted by compressor capacity.

\subsubsection{Air Compressors}

Compressed air is used in most industrial plants and many commercial shops. Unit sizes range from 25 to over 1000 HP. Portable engine-driven air compressors have a long history, and some suppliers are now offering engine-driven systems in larger sizes. Market drivers are similar to those in the chiller and refrigeration markets-reduced energy costs, reduced demand charges, and high part-load efficiency. Heat recovery can improve the economics when applicable.

\subsubsection{Sales of Selected Industrial Prime Movers}

Table 2.2 summarizes annual sales for the three engine-driven markets previously discussed. Engine sales to these markets are $<400$ units a year and currently account for a small percentage of the overall mechanical drive market.

Table 2.2. Mechanical drive market application

\begin{tabular}{lll}
\hline \multicolumn{1}{c}{ Application } & Total annual sales & Annual engine sales \\
\hline Chillers & 2.1 million tons & $<50,000$ tons \\
(industrial and commercial) & 7,000 units & $150-200$ engines \\
Refrigeration & 0.2 million tons & $<5,000$ tons \\
& $600-800$ units & $20-40$ engines \\
Air Compressors & $2000-3000$ units & $<100$ engines \\
& $(>100 \mathrm{HP})$ & \\
\hline
\end{tabular}





\section{BENEFITS OF CHP}

\subsection{INTRODUCTION}

CHP provides many benefits compared to separate heat and power production. These benefits include increased energy efficiency, operating cost savings, and reduced air pollution and global warming. This section describes and quantifies these benefits for the existing and remaining CHP potential installations. Additional benefits for industry include increased reliability, power quality, and higher productivity. The electric power industry and its customers can also benefit when industrial CHP capacity is used to support and optimize the overall power grid.

\subsection{ENERGY BENEFITS}

Power generation systems create large amounts of heat in the process of converting fuel into electricity. For the average central utility power plant, over two-thirds of the energy content of the input fuel is converted to heat and wasted. As an alternative, an end-user with significant thermal and power needs can simultaneously generate thermal and electrical energy in a CHP system located at or near the facility. CHP can significantly increase the efficiency of energy usage as shown in Fig. 3.1.

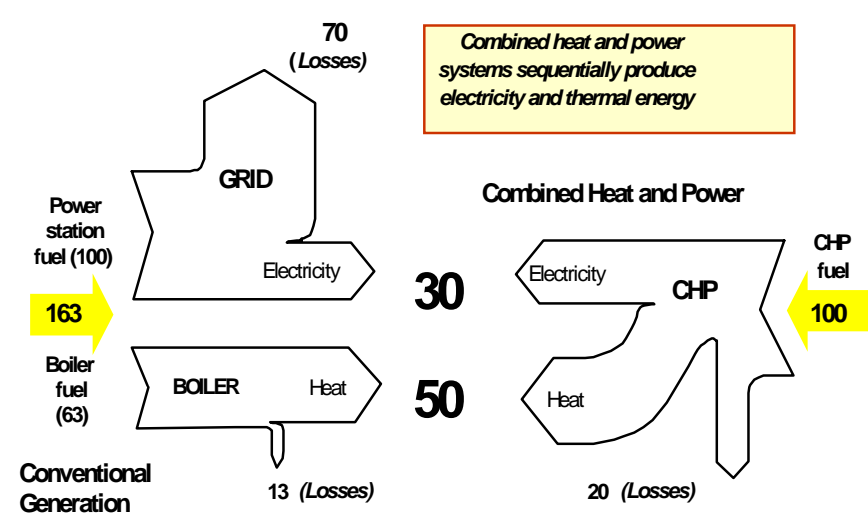

Fig. 3.1. Example of CHP energy savings.

The figure shows that a typical CHP system can reduce energy requirements by close to $40 \%$ compared to separate production of heat and power. For 100 units of input fuel, CHP converts 80 units to useful energy, of which 30 units is electricity and 50 units is for steam or hot water. Traditional separate heat and power components require 163 units of energy to accomplish the same end use tasks* (Kaarsberg and Roop 1999).

\footnotetext{
* Based on Tina Kaarsberg and Joseph Roop, "Combined Heat and Power: How Much Carbon and Energy Can It Save for Manufacturers?" Assumes national averages for existing installed boilers and central generating plants.
} 


\subsection{ENVIRONMENTAL BENEFITS AND EMISSIONS REDUCTION}

By increasing energy efficiency, CHP significantly reduces emissions of criteria pollutants such as $\mathrm{NO}_{\mathrm{x}}$ and $\mathrm{SO}_{2}$, and noncriteria greenhouse gases such as $\mathrm{CO}_{2}$. The IOFs have a stated mission of reducing their emissions, and CHP is an option capable of providing environmental benefits as part of an economically attractive investment. Figures 3.2 and 3.3 show $\mathrm{NO}_{x}$ and $\mathrm{CO}_{2}$ emission comparisons by power generation technology and fuel type. While reductions in both $\mathrm{NO}_{x}$ and $\mathrm{CO}_{2}$ result by switching from solid and liquid fuels to natural gas, the figures show additional reductions brought about by efficiency. CHP technologies can significantly reduce emissions and compare favorably to advanced low- emission central station technologies such as the gas-fired combined cycle.

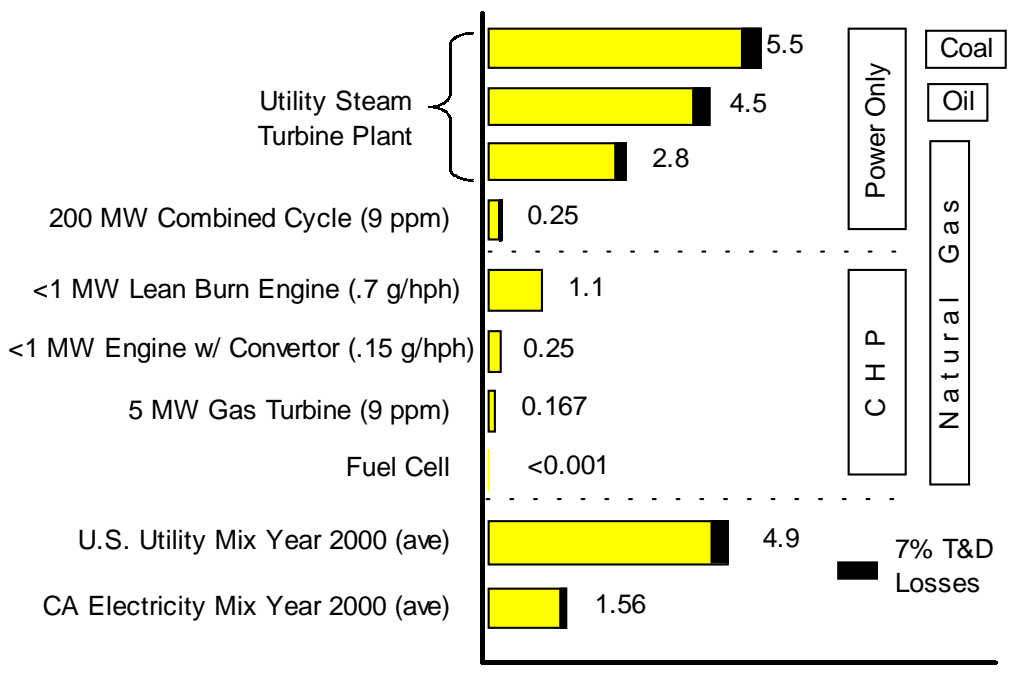

Lbs $\mathrm{NO}_{x} / \mathrm{MWh}$

Fig. 3.2. $\mathrm{NO}_{\mathrm{x}}$ implications of CHP.

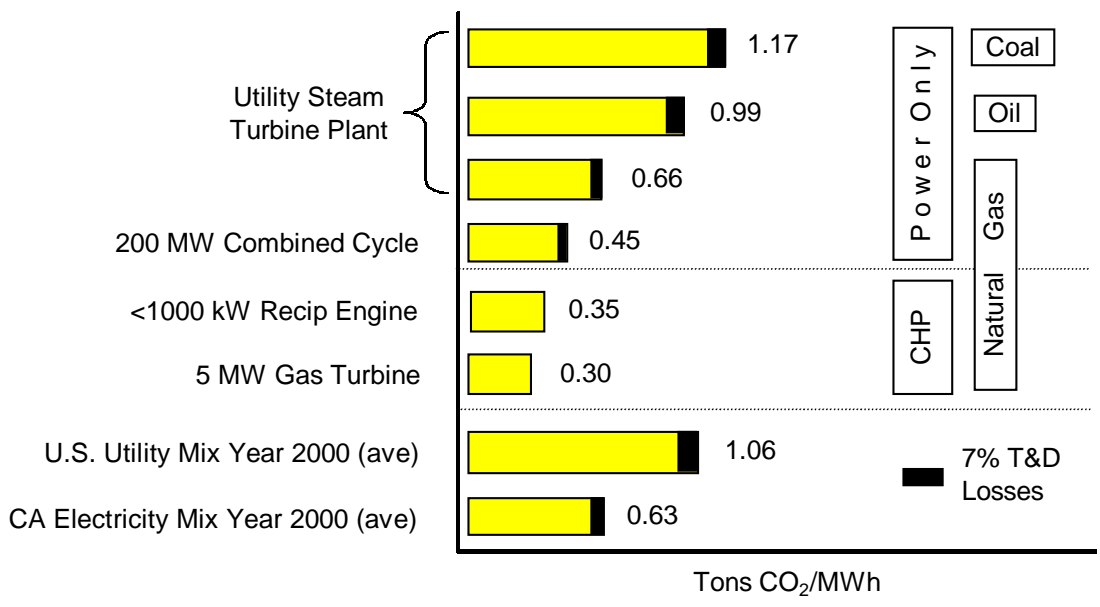

Fig. 3.3. Global warming implications of CHP. 


\subsection{ECONOMIC BENEFITS}

The primary economic driver for CHP is production of power at lower rates than the utility's delivered price. Figure 3.4 demonstrates how CHP compares with traditional central station generation combined with the cost of transmission and distribution (T\&D).

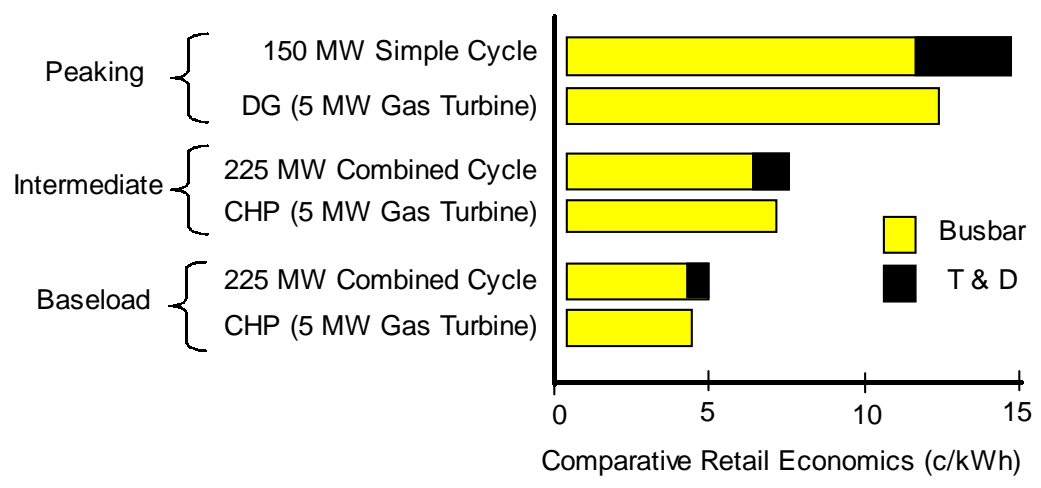

Fig. 3.4. Comparative retail economics of CHP.

By comparison, the cost to produce electricity from a CHP system using an industrial-sized gas turbine, including fuel, capital, and operation and maintenance (O\&M) expenses, is less than $\$ 0.04 / \mathrm{kWh}$ for baseload operation. This cost compares favorably to a baseload central-station, combined-cycle plant at the busbar even before adding T\&D cost. As shown in Fig. 3.4, CHP can compete against large, simplecycle gas turbine plants for intermediate-duty and peaking power after adding T\&D costs. The cost of CHP varies by application, technology, and grid circumstances; but as this example illustrates, economic fundamentals frequently favor CHP. In a restructured power market, end-users may place significant economic value on the stand-by capability and increased reliability that $\mathrm{CHP}$ can provide, further enhancing the potential economic benefits of CHP.

The economics of CHP are compelling when compared to retail power prices. Figure 3.5 compares the cost of power from typical industrial CHP technologies to the electricity price distribution in the industrial sector in the United States. Figure 3.5 shows that a 5-MW combustion turbine CHP system is competitive with delivered electricity prices for $37 \%$ of industrial customers who pay higher rates. For a 30-MW combustion turbine system, CHP is competitive for $68 \%$ of industrial customers. A smaller 1-MW reciprocating engine system is competitive for $20 \%$ of the market. Figure 3.5 is based on a $\$ 3.50 / \mathrm{MMBtu}$ gas cost for the CHP system and avoided cost for boiler fuel.

The competitive market shares for each CHP system are sensitive to the cost of natural gas. Figure 3.6 shows how the competitive industrial market share changes for gas prices between $\$ 2.50$ and $\$ 4.75 / \mathrm{MMBtu}$. For gas prices of $\$ 2.50 / \mathrm{MMBtu}$, a $30-\mathrm{MW}$ CHP system is competitive in $90 \%$ of the industrial market; for gas price of $\$ 4.75 / \mathrm{MMBtu}$, the competitive share drops to $43 \%$. For a 1-MW and 5-MW CHP system, the corresponding competitive market shares range from $9 \%$ to $33 \%$ and from $20 \%$ to $64 \%$, respectively. 


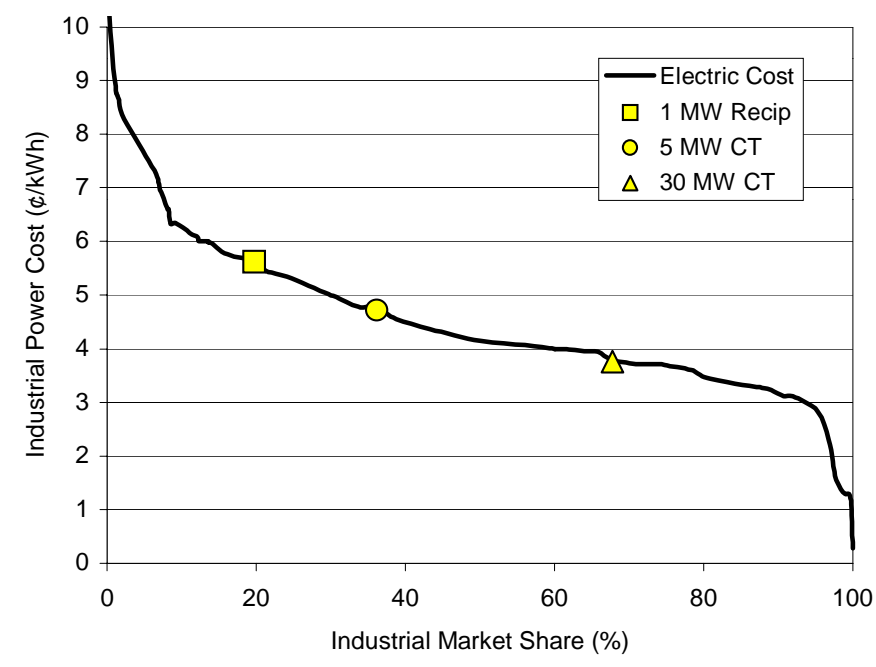

Fig. 3.5. CHP competitive industrial market share.

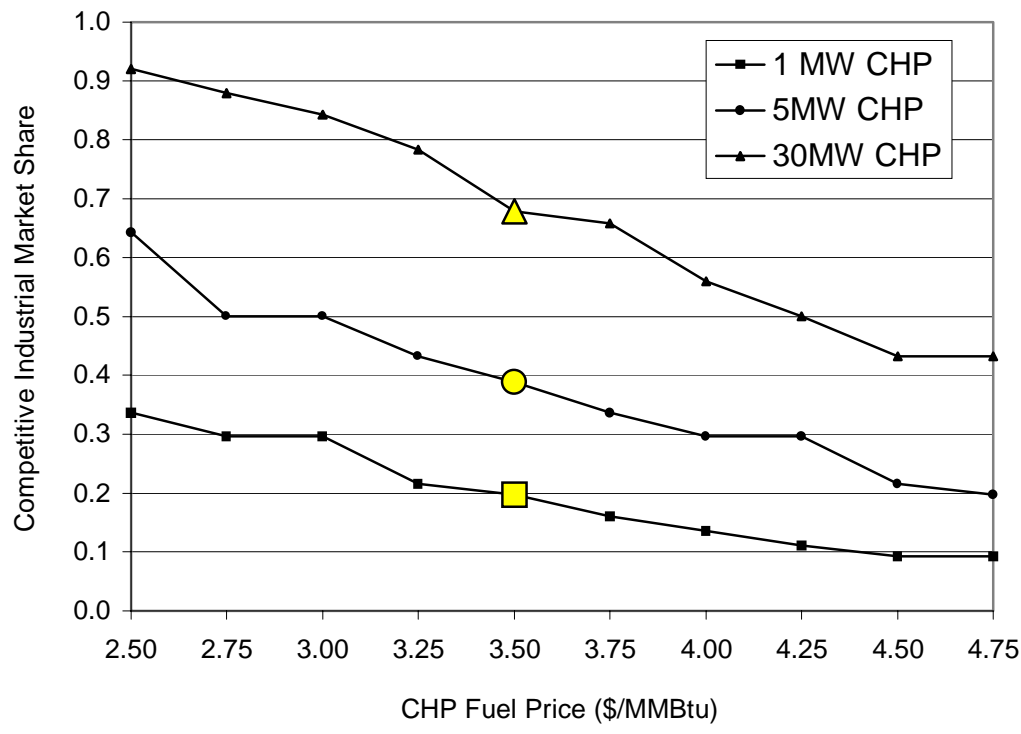

Fig. 3.6. Effect of CHP fuel price on competitive industrial market share.

\subsection{ANCILLARY BENEFITS}

In a restructured power market, CHP and other on-site generation options can offer grid support to the local distribution utility. On-site generation ancillary benefits to the grid include

- voltage and frequency support to enhance reliability and power quality;

- avoidance or deferral of high cost, long lead time T\&D upgrades;

- bulk power risk management;

- reduced line losses, reactive power control; 
- $\quad$ outage cost savings;

- reduced central station generating reserve requirements; and

- transmission capacity release.

CHP offers customers enhanced reliability, operational and load-management flexibility, ability to arbitrage electric and gas prices, and energy-management techniques, including peak shaving and thermal energy storage. The value of these benefits depends on the characteristics of the facility, energy use and prices, load profiles, and electric rate tariffs, etc. When considering a CHP investment, users should factor in the possible ancillary benefits, including the revenue stream from sale of T\&D benefits to the independent system operator (or equivalent) and reduced operating costs, along with the other costs and benefits of the project.

\subsection{BENEFITS CALCULATION FOR EXISTING AND POTENTIAL INDUSTRIAL CHP}

The estimated energy, economic, and emissions benefits were developed for the existing and remaining CHP market potential. Table 3.1 shows representative CHP technologies and their cost and performance characteristics for four size bins between 0.1 MW and >20 MW (Onsite Energy Corporation 2000).

Table 3.1. Representative CHP cost and performance

\begin{tabular}{llcccrc}
\hline $\begin{array}{c}\text { Size } \\
\text { range } \\
(\mathrm{MW})\end{array}$ & $\begin{array}{c}\text { Representative } \\
\text { technology }\end{array}$ & $\begin{array}{c}\text { Electrical } \\
\text { efficiency } \\
(\%)\end{array}$ & $\begin{array}{c}\text { Recovered } \\
\text { heat } \\
(\mathrm{Btu} / \mathrm{kWh})\end{array}$ & $\begin{array}{c}\text { Heat used } \\
(\%)\end{array}$ & $\begin{array}{c}\text { Capital cost } \\
(\$ / \mathrm{kW})\end{array}$ & $\begin{array}{c}\text { O\&M cost } \\
(\$ / \mathrm{kWh})\end{array}$ \\
\hline $0.1-1$ & Recip. engine & 31.3 & 4,100 & 80 & $\$ 980$ & $\$ 0.0132$ \\
$1-4$ & Gas turbine & 27.6 & 5,600 & 80 & $\$ 1,150$ & $\$ 0.0059$ \\
$4-20$ & Gas turbine & 29.0 & 5,300 & 90 & $\$ 980$ & $\$ 0.0055$ \\
$>20$ & Gas turbine & 37.0 & 3,800 & 90 & $\$ 700$ & $\$ 0.0042$ \\
\hline
\end{tabular}

\subsubsection{Energy Savings}

The total annual energy savings attributable to existing and remaining industrial CHP are shown in Table 3.2 using the stated assumptions for annual load factor, average utility heat rate, T\&D losses, and typical boiler efficiency. Results indicate that the existing $44 \mathrm{GW}$ of industrial CHP saves 1.5 quads of energy per year, and the remaining potential of $88 \mathrm{GW}$ could save an additional 2.7 quads of energy per year.

Table 3.3 shows the net overall cost savings that are calculated by subtracting the total cost of CHP fuel, O\&M, and capital from the annual savings. CHP cost savings are estimated for avoided electric power purchases and avoided boiler fuel using the cost and performance estimates for the representative technologies shown in Table 3.1. These calculations show that existing CHP saves U.S. industry nearly $\$ 2.5$ billion annually, and the remaining CHP potential could save an additional $\$ 5.4$ billion annually. If all of the remaining industrial CHP potential were implemented, the current $\$ 69$ billion U.S. annual energy bill could be reduced by about $8 \%$. 
Table 3.2. Net energy savings for industrial CHP

\begin{tabular}{|c|c|c|c|c|c|c|}
\hline $\begin{array}{l}\text { Size range } \\
(\mathrm{MW})\end{array}$ & $\begin{array}{l}\text { CHP capacity } \\
\text { (MW) }\end{array}$ & $\begin{array}{l}\text { CHP output } \\
\text { (GWh) }\end{array}$ & $\begin{array}{c}\text { CHP } \\
\text { energy used }\end{array}$ & $\begin{array}{c}\text { Avoided } \\
\text { utility electric }\end{array}$ & $\begin{array}{c}\text { Avoided } \\
\text { thermal }\end{array}$ & $\begin{array}{c}\text { Net energy } \\
\text { saved }\end{array}$ \\
\hline \multicolumn{3}{|c|}{ Existing $\mathrm{CHP}$} & \multicolumn{4}{|c|}{ (Quads) } \\
\hline $0.1-1$ & 60 & 360 & 0.004 & 0.004 & 0.001 & 0.001 \\
\hline $1-4$ & 369 & 2,214 & 0.027 & 0.024 & 0.012 & 0.009 \\
\hline $4-20$ & 2,442 & 14,652 & 0.172 & 0.158 & 0.087 & 0.073 \\
\hline$>20$ & 41,372 & 248,232 & 2.290 & 2.685 & 1.055 & 1.450 \\
\hline Total & 44,243 & 265,458 & 2.493 & 2.871 & 1.156 & 1.534 \\
\hline \multicolumn{7}{|c|}{ Remaining CHP potential } \\
\hline $0.1-1$ & 21,930 & 131,580 & 1.437 & 1.423 & 0.539 & 0.525 \\
\hline $1-4$ & 6,070 & 36,420 & 0.450 & 0.394 & 0.204 & 0.148 \\
\hline $4-20$ & 11,337 & 68,022 & 0.799 & 0.736 & 0.404 & 0.341 \\
\hline$>20$ & 48,983 & 293,898 & 2.711 & 3.179 & 1.249 & 1.717 \\
\hline Total & 88,320 & 529,920 & 5.397 & 5.731 & 2.397 & 2.730 \\
\hline
\end{tabular}

Assumptions:

Average utility heat rate (Btu/kWh): 10,300.

Average T\&D losses: 5\%.

Average CHP hours of operation: 6,000.

Existing boiler efficiency: $80 \%$.

Table 3.3. Economic savings from industrial CHP

\begin{tabular}{|c|c|c|c|c|c|}
\hline \multirow{3}{*}{$\begin{array}{l}\text { Size range } \\
(\mathrm{MW})\end{array}$} & \multicolumn{2}{|c|}{ Savings } & \multirow{3}{*}{$\begin{array}{c}\text { Costs } \\
\text { CHP cost to } \\
\text { generate power } \\
(\$ / \mathrm{kWh})\end{array}$} & \multirow{2}{*}{\multicolumn{2}{|c|}{ Net savings }} \\
\hline & \multirow{2}{*}{$\begin{array}{c}\text { Avoided } \\
\text { utility power } \\
(\$ / \mathrm{kWh})\end{array}$} & \multirow{2}{*}{$\begin{array}{c}\text { Avoided } \\
\text { boiler fuel } \\
(\$ / \mathrm{kWh})\end{array}$} & & & \\
\hline & & & & $(\$ / \mathrm{kWh})$ & $($ million \$) \\
\hline \multicolumn{6}{|c|}{ Existing $C H P$} \\
\hline $0.1-1$ & $\$ 0.070$ & $\$ 0.012$ & $(\$ 0.067)$ & $\$ 0.015$ & $\$ 5.4$ \\
\hline $1-4$ & $\$ 0.060$ & $\$ 0.017$ & $(\$ 0.068)$ & $\$ 0.009$ & $\$ 20$ \\
\hline $4-20$ & $\$ 0.050$ & $\$ 0.018$ & $(\$ 0.062)$ & $\$ 0.006$ & $\$ 80$ \\
\hline$>20$ & $\$ 0.044$ & $\$ 0.013$ & $(\$ 0.047)$ & $\$ 0.009$ & $\$ 2,350$ \\
\hline Total & & & & & $\$ 2,460$ \\
\hline \multicolumn{6}{|c|}{ Remaining CHP potential } \\
\hline $0.1-1$ & $\$ 0.070$ & $\$ 0.012$ & $(\$ 0.067)$ & $\$ 0.015$ & $\$ 1,970$ \\
\hline $1-4$ & $\$ 0.060$ & $\$ 0.017$ & $(\$ 0.068)$ & $\$ 0.009$ & $\$ 310$ \\
\hline $4-20$ & $\$ 0.050$ & $\$ 0.018$ & $(\$ 0.062)$ & $\$ 0.006$ & $\$ 390$ \\
\hline$>20$ & $\$ 0.044$ & $\$ 0.013$ & $(\$ 0.047)$ & $\$ 0.009$ & $\$ 2,790$ \\
\hline Total & & & & & $\$ 5,450$ \\
\hline
\end{tabular}

Assumptions:

Natural gas cost \$/MMBtu: \$3.00.

Capital recovery factor (15 year life, $10 \%$ return on investment): $13.15 \%$. 


\subsubsection{Environmental Benefits}

CHP technologies also provide environmental benefits. Table 3.4 shows the reduction in $\mathrm{NO}_{\mathrm{x}}$ emissions, and Table 3.5 shows the reduction in $\mathrm{CO}_{2}$ emissions, a primary contributor to global warming. Assuming that gas-fired $\mathrm{CHP}$ technologies would offset coal-fired power generation, substantial reductions in $\mathrm{SO}_{2}$ emissions would occur.

Table 3.4. Reduction in $\mathrm{NO}_{\mathrm{x}}$ emissions with industrial CHP

\begin{tabular}{|c|c|c|c|c|c|c|}
\hline $\begin{array}{l}\text { Size range } \\
\text { (MW) }\end{array}$ & $\begin{array}{c}\text { CHP capacity } \\
\text { (MW) }\end{array}$ & $\begin{array}{l}\text { CHP output } \\
\text { (GWh) }\end{array}$ & $\begin{array}{l}\text { CHP emissions } \\
\text { (lb/MWh) }\end{array}$ & $\begin{array}{l}\text { Average utility } \\
\text { emissions } \\
\text { (lb/MWh) }\end{array}$ & $\begin{array}{c}\text { Boiler } \\
\text { emissions } \\
\text { (lb/MMBtu) }\end{array}$ & $\begin{array}{c}\text { Avoided } \mathrm{NO}_{\mathrm{x}} \\
\text { emissions } \\
\text { (tons/year) }\end{array}$ \\
\hline \multicolumn{7}{|c|}{ Existing $C H P$} \\
\hline $0.1-1$ & 60 & 360 & 2.957 & 4.485 & 0.035 & 300 \\
\hline $1-4$ & 370 & 2,200 & 1.113 & 4.485 & 0.035 & 3,900 \\
\hline $4-20$ & 2,400 & 14,600 & 1.113 & 4.485 & 0.035 & 26,200 \\
\hline$>20$ & 41,400 & 248,000 & 0.764 & 4.485 & 0.035 & 480,300 \\
\hline Total & 44,200 & 265,000 & & & & 510,700 \\
\hline \multicolumn{7}{|c|}{ Remaining CHP Potential } \\
\hline $0.1-1$ & 21,930 & 131,580 & 0.440 & 0.150 & 0.035 & $-9,700$ \\
\hline $1-4$ & 6,070 & 36,420 & 0.124 & 0.150 & 0.035 & 4,100 \\
\hline $4-20$ & 11,337 & 68,022 & 0.124 & 0.150 & 0.035 & 8,000 \\
\hline$>20$ & 48,983 & 293,898 & 0.085 & 0.150 & 0.035 & 31,400 \\
\hline Total & 88,320 & 529,920 & & & & 33,800 \\
\hline
\end{tabular}

Assumptions:

Existing reciprocating engine emissions are $1 \mathrm{~g} / \mathrm{bhp}-\mathrm{h}$.

Existing gas turbine emissions are assumed to be $0.09 \mathrm{lb} / \mathrm{MMBtu}$.

Emissions for new technology is assumed to represent $85-90 \%$ reduction.

EIA estimated that the electric utility industry produced 7.2 million tons of $\mathrm{NO}_{\mathrm{x}}$ in 1998. Based on electricity sales of 3.2 trillion $\mathrm{kWh} /$ year, this represents an average emissions factor of $4.49 \mathrm{lb} / \mathrm{MWh}$ for the power industry. This average emissions rate is well above new performance standards for the industry of about $0.15 \mathrm{lb} / \mathrm{MWh}$. This analysis used the average industry emissions to measure the benefits of existing CHP and used the new performance standards to measure the benefits of penetrating the remaining CHP potential. The latter assumption is probably over conservative and yields a minimum savings. The CHP emissions factors were estimated to reflect typical performance of existing CHP systems and also the performance of state-of-the-art units that could be installed for future market penetration. Compared to existing units, new installations can achieve an 85-90\% reduction in emissions achievable by new installations using extensive controls. The table shows that existing industrial CHP units save over 500 thousand tons/year of $\mathrm{NO}_{\mathrm{x}}$ emissions compared to average utility and boiler $\mathrm{NO}_{\mathrm{x}}$ emissions. The remaining CHP potential will most likely compete against much cleaner utility power technology. Therefore, even though new CHP is much cleaner, the benefits are comparatively smallerabout 34 thousand tons of $\mathrm{NO}_{\mathrm{x}} /$ year can be avoided. 
Table 3.5. Reduction in $\mathrm{CO}_{2}$ emissions with industrial CHP

\begin{tabular}{|c|c|c|c|c|c|c|}
\hline $\begin{array}{l}\text { Size } \\
\text { range } \\
(\mathrm{MW})\end{array}$ & $\begin{array}{l}\text { CHP capacity } \\
\text { (MW) }\end{array}$ & $\begin{array}{l}\text { CHP output } \\
\text { (GWh) }\end{array}$ & $\begin{array}{l}\text { CHP emissions } \\
\text { (lb/MWh) }\end{array}$ & $\begin{array}{c}\text { Average utility } \\
\text { emissions } \\
\text { (lb/MWh) }\end{array}$ & $\begin{array}{c}\text { Boiler } \\
\text { emissions } \\
\text { (lb/MMBtu) }\end{array}$ & $\begin{array}{c}\text { Avoided } \mathrm{CO}_{2} \\
\text { emissions } \\
\text { (1000 tons/year) }\end{array}$ \\
\hline \multicolumn{7}{|c|}{ Existing $C H P$} \\
\hline $0.1-1$ & 60 & 360 & 1,310 & 1,372 & 120 & 100 \\
\hline $1-4$ & 370 & 2,200 & 1,352 & 1,372 & 120 & 770 \\
\hline $4-20$ & 2,400 & 14,700 & 1,410 & 1,372 & 120 & 4,900 \\
\hline$>20$ & 41,400 & 248,200 & 1,107 & 1,372 & 120 & 96,200 \\
\hline Total & 44,200 & 265,500 & & & & 102,000 \\
\hline \multicolumn{7}{|c|}{ Remaining CHP Potential } \\
\hline $0.1-1$ & 21,900 & 131,600 & 1,310 & 1,372 & 120 & 36,400 \\
\hline $1-4$ & 6,10 & 36,400 & 1,352 & 1,372 & 120 & 12,600 \\
\hline $4-20$ & 11,300 & 68,000 & 1,410 & 1,372 & 120 & 23,000 \\
\hline$>20$ & 49,000 & 293,900 & 1,107 & 1,372 & 120 & 114,000 \\
\hline Total & 88,300 & 529,900 & & & & 186,000 \\
\hline
\end{tabular}

CHP technologies reduce $\mathrm{CO}_{2}$ emissions because of their high efficiency and their reliance on natural gas. Natural gas contributes less $\mathrm{CO}_{2}$ per unit of energy than either coal or oil. The power industry's heavy reliance on coal for power production creates a high level of greenhouse gas emissions. The utility industry as a whole emits $1,372 \mathrm{lb} / \mathrm{MWh}$ of $\mathrm{CO}_{2}$. This average includes all of the hydroelectric and nuclear output that do not directly contribute to $\mathrm{CO}_{2}$ emissions. The estimates for each CHP size range reflect the changes due to the electrical efficiency of the technology. Existing CHP in the industrial sector saves 102 million tons/year of $\mathrm{CO}_{2}$. Penetration of the remaining CHP market potential would save an additional 185 million tons/year. Considering the total CHP potential as a whole, the $\mathrm{CO}_{2}$ emissions reduction could reflect $15 \%$ of the total power industry emissions. 


\section{CONCLUSIONS AND RECOMMENDATIONS}

This section provides an overall assessment of the opportunities and barriers for on-site power generation in the industrial sector and in the IOFs.

\subsection{MARKET ANALYSIS CONCLUSIONS}

The analysis of the existing CHP market and remaining potential within the IOFs and the industrial sector suggest the following key conclusions.

- IOFs represent $77 \%$ of the total industrial potential with $92 \%$ of existing CHP and $69 \%$ of remaining industrial market potential. The highest potential for CHP in the IOFs is in the chemical, forest products, refining, and food processing industries. Mining, glass, and metals casting show the lowest market potential for CHP.

- The highest potential outside the IOFs are in the fabrication industries, textiles, and rubber. The fabrication industries such as machinery and transportation equipment show a strong potential for effective use of CHP. Textiles, rubber, and plastics have a significant level of existing CHP and potential to use a large number of additional CHP installations.

- Much of the remaining CHP potential is within industries that have traditionally employed CHP. Two-thirds of the remaining CHP potential is in five industries (food, paper, chemicals, refining, and primary metals) that currently have significant levels (>25\%) of CHP saturation.

- Existing CHP capacity represents about one-third of the total CHP market. Certain industries such as chemicals and petroleum refining have higher saturation of rates $65 \%$ and $45 \%$, respectively.

- Previous CHP development has focused on large systems. More than $90 \%$ of existing CHP capacity in the industrial market is represented by systems of $20 \mathrm{MW}$ or greater. Over $45 \%$ of existing CHP capacity is in this size range.

- Large systems represent a significant share of the remaining CHP market potential with 55\% of the remaining CHP potential representing systems $20 \mathrm{MW}$ or greater.

- Small systems also represent a large untapped market for CHP with $32 \%$ of the remaining CHP market potential represented by systems $<4 \mathrm{MW}$. Market saturation for small CHP is currently very low with $7 \%$ for systems $<20 \mathrm{MW}$ and $1 \%$ for systems $<4 \mathrm{MW}$.

\subsection{TECHNOLOGY RESEARCH NEEDS}

CHP technology is well established and economically effective. The market potential estimates are based on current state-of-the-art technology. However, technical improvements can expand the rate of adoption and increase the number of sites where CHP is the best economic solution. Government and industry partnerships can accelerate development in the following areas.

- Cooperative research to enhance efficiency and lower emissions in gas turbines and reciprocating engines will help to expand the utility and ease of siting these important commercial technologies. 
- Development and demonstration of emerging technologies such as high-temperature fuel cells and hybrids that can provide high efficiency and ultra-low emissions for the industrial sector.

- Reduced component costs, improved performance, and reduced packaging, siting, and installation costs for small CHP systems.

- Government and industry partnerships to demonstrate small CHP systems, recognizing a virtually untapped market with a high potential. A targeted demonstration program will help to prove the feasibility and reliability of clean technology, process integrated systems, mechanical drive applications, grid support, and other novel approaches.

- Development of simplified grid interconnection and control technology, especially for smaller systems, will provide new opportunities for CHP systems.

- Cost reduction in exhaust treatment systems, and demonstration of catalytic combustion and clean technologies will facilitate siting of small CHP.

- Development of fuel-flexible systems to use multiple fuels with the capability to switch-on-the-fly. The emergence of competitive power, natural gas, and other fuel markets will reward systems that can switch fuels when necessary without loss of efficiency or environmental performance.

- Improvements in production, refining, and utilization of biofuels will help to promote the development and use of renewable CHP.

\subsection{MARKET AND REGULATORY NEEDS}

Government and industry partnerships can help to remove market and regulatory barriers to CHP. The following list of initiatives are taken from the CHP Challenge Vision Statement (United States Combined Heat and Power Association 1999).

- Uniform interconnection standards accepted by all fifty states and supported by professional organizations (e.g., the Institute of Electrical and Electronics Engineers and the American Society of Heating, Refrigerating and Air-Conditioning Engineers)

- Industry restructuring initiatives that provide for all utility/CHP transactions to be based on competitive market forces

- Output-based emissions standard that considers the amount of useful work performed rather than the current end-of-pipe volumetric approach

- Streamlined permitting process

- Favorable tax and depreciation policies for CHP that are consistent with project expectations and life

- Information, education, and training programs to enhance industry awareness

- Selected fiscal policies to help industrial decision makers internalize the social benefits of lower emissions, reduced global warming, energy security, and economic development due to implementation of CHP systems

- Reduction of international market barriers to increase export of products and services 


\subsection{INDUSTRY-SPECIFIC INITIATIVES}

Many industrial energy managers value power and steam systems secondarily to their core business. A notable exception is the paper industry, which has integrated on-site generation with process recovery and waste elimination. Examples of process-integrated CHP can be seen in other industries, including chemicals, refining, steel, and food manufacture. Opportunities exist to promote CHP as part of the IOF initiatives that are designed to address productivity, waste, emissions, and global warming.

\subsubsection{Agriculture}

The vision statement for the agricultural sector is focused on research and development of industrial chemicals made from biomass or renewable resources. The near-term targets for research include development of high-efficiency combined processes that will increase the use of by-products. Integrating CHP with the manufacture of biofuels can improve the economics of the process while reducing the adverse impacts of waste streams such as crop residues and animal wastes. Further research is needed to enable reliable, efficient use of biofuels.

\subsubsection{Food Processing}

The food processing sector represents an important market for on-site generation and in particular for systems $<50 \mathrm{MW}$ in capacity. The food industry is an extension of the agricultural sector in many respects, exemplified by the development of biofuels.

Utilization of solid waste coupled with advances in biomass gasification is expected to increase implementation of cost-effective, power-generation alternatives. An example is the use of biomass to cofire conventional power plants. These biofuel initiatives represent opportunities for waste-stream utilization, sustainable energy sources, safe cultivation of soils prone to erosion, and recycling of atmospheric carbon. The most notable CHP opportunities in the food processing sector include meat preparation and packing, flour and grains, poultry, malt beverages, and fruit and vegetables processing and freezing processes.

\subsubsection{Mining Industry}

The vision statement for the mining industry has an objective to efficiently use energy and raw materials while minimizing the volume of waste. Coal producers and users can mitigate $\mathrm{CO}_{2}$ emissions in the generation of electricity from coal through improved efficiency, de-carbonization and carbon dioxide sequestration. The mining industry recognizes the importance of coal as an energy and chemical feedstock. The deployment of on-site generation in this industry will rely on the use of waste streams such as coal seam gas, gob gas, coal fines, and mitigation of environmental issues.

\subsubsection{Forest Products Industry}

The forest products industry satisfies $57 \%$ of its requirements from renewable fuels and is one of the largest consumers of fossil fuels and power. The vision statement recognizes substantial synergy between energy self-sufficiency and waste streams for power generation and environmental. The successful gasification of black liquor and waste biomass could improve energy self-sufficiency and help achieve reduced levels of emissions to the air. 


\subsubsection{Chemical Industry}

The chemical sector has already made gains in energy efficiency and continues to invest in R\&D and capital equipment for increased productivity and decreased environmental pollution. The vision statement identifies various energy-related opportunities that merit further attention. The chemical industry needs to foster the development of smaller on-site power projects, to complement their significant experience with larger CHP systems. The chemical industry is developing gas clean-up technologies for gas turbines that consume waste streams. By combining clean-up technologies with gasification processes, the chemical industry will benefit from a diversified fuel feedstock inventory, and more cost-effective options to deploy on-site generation. The sub-sectors having the most on-site generation potential are the plastics, pharmaceutical and fertilizer sectors, and the industrial gases.

\subsubsection{Petroleum Refining Industry}

The petroleum refining industry uses its own by-products and waste streams as energy sources, and has an established track record in CHP applications to meet its thermal and electric needs. With up to $40 \%$ of its variable costs accountable to heat and power, this industry is highly sensitive to the cost of delivered energy. The pressure to maintain profitability will motivate refiners to install new CHP systems. Smaller capacity systems do exist in related industrial activities such as the production of lubes, oils, asphalt, coatings, and other related petroleum products.

\subsubsection{Glass Industry}

The vision statement for this industry has as one of its goals to enhance energy usage through the development of improved waste-heat recovery, including CHP. Currently $15 \%$ of the cost to produce glass is attributable to energy. Enhanced heat recovery like CHP is expected to lower energy expenditures, increase productivity, and mitigate environmental issues. Research efforts include optimizing electric boost to reduce total energy consumption and designing new furnace that operate more efficiently. Integrating energy-efficient fuels into manufacturing processes and waste-heat recovery are also research priorities.

\subsubsection{Steel Industry}

The steel industry's vision statement recommends four areas of opportunity to improve energy and environmental performance: process efficiency, recycling, environmental engineering, and product development. The current vision for the steel industry does not specifically address CHP as a priority. However, the energy intensity of this industry coupled with the need to remain cost competitive and environmentally responsible will motivate steel makers to examine the multiple benefits of CHP.

\subsubsection{Aluminum Industry}

Primary aluminum production has high electric demands but limited need for steam. In large integrated mills, however, opportunities exist to use the heat from a CHP system. Applications in various mill operations need to be explored. Opportunities may exist to integrate CHP systems within hazardous waste cleanup systems.

\subsubsection{Metal Casting}

The metal casting industry is a relatively small sector compared to the other IOFs. This industry consists of a large number of independent facilities as well as captive shops within other manufacturing industries. Steam requirements at the independent facilities are limited. The industry has been faced with a variety of 
environmental constraints on solid wastes and hazardous materials. Some of the developing reclamation technologies could be more effective and less costly if integrated with CHP.

\subsubsection{Non-IOFs}

A significant opportunity exists for CHP in non-IOF industries. Textile manufacturing is based on agricultural products and could benefit from improvements in the agricultural sector regarding waste treatment and recovery systems. Equipment manufacturing industries, including fabricated metal products, electrical equipment, transportation equipment, and instruments, have diverse requirements. However, many of these industries may share common processes such as parts cleaning, paint booths, and compressed air tool systems that could be integrated with CHP systems. A large market opportunity exists for smaller capacity CHP systems with lower quality thermal output. 



\section{BIBLIOGRAPHY}

DOE EIA (Department of Energy, Energy Information Administration). 1994. Manufacturing Energy Consumption Survey.

DOE EIA (Department of Energy, Energy Information Administration). 1998. The Changing Structure of the Electric Power Industry: Selected Issues, 1998, July.

Kaarsberg, T. M. and J. M. Roop. 1998. "Combined Heat and Power: How Much Carbon and Energy Can It Save for Manufacturers?" IECEC-98-I209 33rd Intersociety Engineering Conference on Energy Conversion, Colorado Springs, CO, August 2-6.

Onsite Energy Corporation. 2000. Analytic and Data Support for NEMS Industrial Cogeneration Modeling (Draft), DOE Energy Information Administration, January 27.

Petroleum Information/Dwights. 1998. Major Industrial Plant Database. November.

United States Combined Heat and Power Association. 1999. Combined Heat and Power: A Vision for the Future of CHP in the U.S. in 2020, September. 



\section{APPENDIX A \\ ENERGY USE IN THE IOFS}

\section{A.1 IMPORTANCE OF THE IOFS TO THE U.S. ECONOMY}

With a combined shipment value of over $\$ 1.8$ trillion and expenditures that exceed $\$ 16$ billion per year for electricity, the IOFs represent a formidable segment of the industrial output of the United States. Table A.1 provides a comparison of economic statistics for the IOFs and the food industry.

Table A.1. Economic statistics

\begin{tabular}{|c|c|c|c|c|c|c|c|c|}
\hline IOF & $\begin{array}{l}\text { Value of } \\
\text { shipment }^{1} \\
\text { ( } \$ \text { billion) }\end{array}$ & $\begin{array}{c}\text { Total } \\
\text { workers }{ }^{1}\end{array}$ & $\begin{array}{c}\text { Capital } \\
\text { expenses }{ }^{2} \\
(\$ \text { million })\end{array}$ & $\begin{array}{l}\text { Net trade } \\
\text { balance } \\
\text { (\$ billion) }\end{array}$ & $\begin{array}{l}\text { Energy } \\
\text { use }^{3} \\
\text { (quads) }\end{array}$ & $\begin{array}{c}\text { Energy } \\
\text { costs } \\
(\$ \text { million })\end{array}$ & $\begin{array}{l}\text { Pollution } \\
\text { control costs } \\
\text { (\$ million) }\end{array}$ & $\begin{array}{c}\text { Average } \\
{ }^{2} \text { earnings }{ }^{1} \\
(\$ / \mathrm{h})\end{array}$ \\
\hline Agriculture & $\$ 226$ & $2,900,000$ & $\$ 14,000$ & $\$ 22.00$ & 1.0 & n.a. ${ }^{4}$ & n.a. & $\$ 10.19$ \\
\hline Mining $^{5}$ & $\$ 158$ & 550,137 & n.a. & n.a. & 2 & n.a. & n.a. & $\$ 19.28$ \\
\hline Food & $\$ 480$ & $1,567,155$ & $\$ 9,900$ & n.a. & 1.2 & 5,548 & $\$ 1,450$ & $\$ 13.14$ \\
\hline $\begin{array}{l}\text { Forest } \\
\text { products }\end{array}$ & $\$ 271$ & $1,380,733$ & $\$ 13,200$ & $(\$ 5.40)$ & 3.2 & 7,732 & $\$ 3,110$ & $\$ 14.74$ \\
\hline Chemicals & $\$ 404$ & 843,469 & $\$ 34,000$ & $\$ 17.00$ & 5.5 & 18,007 & $\$ 7,140$ & $\$ 21.80$ \\
\hline $\begin{array}{l}\text { Petroleum } \\
\text { refining }\end{array}$ & $\$ 173$ & 106,863 & $\$ 522$ & $(\$ 5.20)$ & 5.9 & 3,180 & $\$ 5,400$ & $\$ 21.64$ \\
\hline Glass & $\$ 27$ & 150,400 & $\$ 1,900$ & $(\$ 0.44)$ & 0.3 & 3,630 & $\$ 285$ & $\$ 13.96$ \\
\hline Steel & $\$ 68$ & 221,000 & $\$ 3,100$ & $(\$ 11.40)$ & 1.8 & 6,630 & $\$ 1,400$ & $\$ 18.83$ \\
\hline Aluminum & $\$ 35$ & 143,000 & $\$ 593$ & $(\$ 3.00)$ & 0.4 & 1,319 & $\$ 283$ & $\$ 15.45$ \\
\hline $\begin{array}{l}\text { Metal } \\
\quad \text { casting }\end{array}$ & $\$ 22$ & 217,000 & $\$ 966$ & $(\$ 24.00)$ & 0.2 & 1,334 & $\$ 381$ & $\$ 13.12$ \\
\hline Total & $\$ 1,867$ & $8,079,757$ & $\$ 78,181$ & $(\$ 10.44)$ & 21.8 & 47,380 & $\$ 19,449$ & \\
\hline $\begin{array}{l}{ }^{1} \text { Source: } 19 \\
{ }^{2} \text { Source: In } \\
{ }^{3} \text { Source: D } \\
{ }^{4} \text { n.a. = stat }\end{array}$ & $\begin{array}{l}7 \text { Economi } \\
\text { ividual IOF } \\
\text { E EIA } 199 \\
\text { tics not av }\end{array}$ & $\begin{array}{l}\text { c Census: } \\
\text { vision state } \\
4 \text { Manufact } \\
\text { ailable. }\end{array}$ & $\begin{array}{l}\text { omparative } \\
\text { ements. } \\
\text { uring Energ }\end{array}$ & $\begin{array}{l}\text { Statistics } \\
\text { Consump }\end{array}$ & $\begin{array}{l}\text { for the } L \\
\text { ption Sul }\end{array}$ & $\begin{array}{l}\text { United State } \\
\text { rvey. }\end{array}$ & & \\
\hline
\end{tabular}

Figure A.1 shows shipment value for the IOFs and the food industry. The food industry accounts for the largest shipment value, followed by the chemical industry, forest products, agriculture, and mining. The IOFs provide the basic materials for virtually all economic activities. 


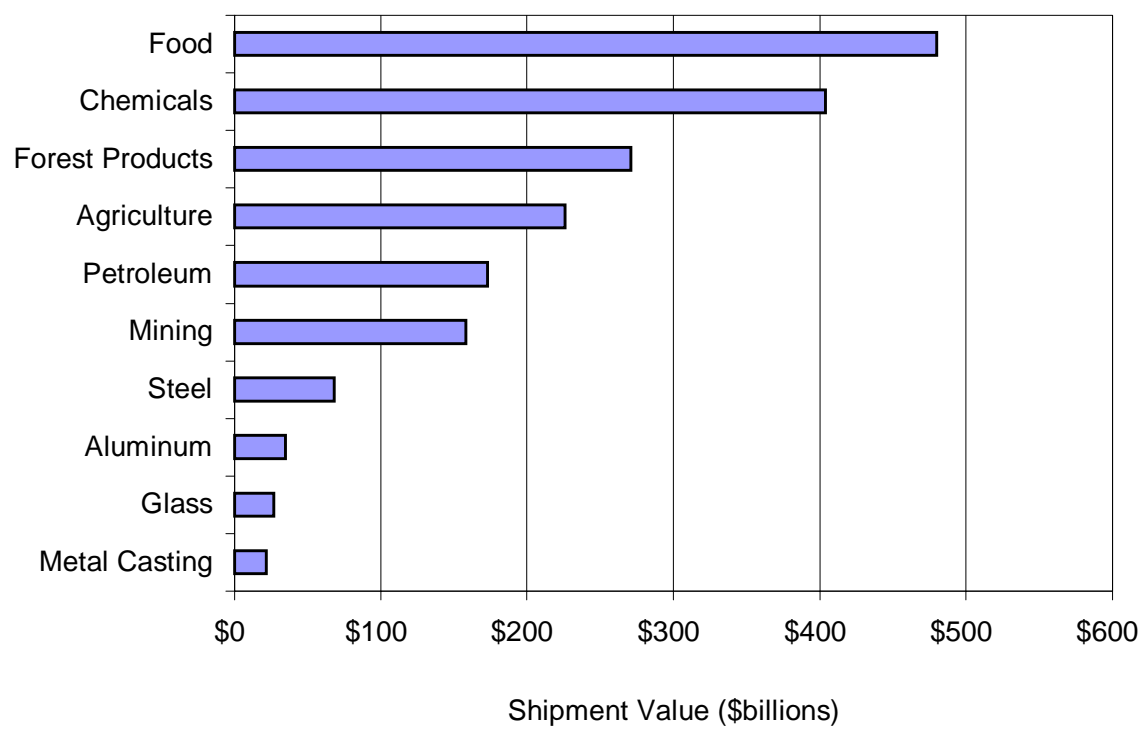

Fig. A.1. Shipment value for 1997.

\section{A.2 AGRICULTURE}

Agriculture encompasses farming, biofeed stocks for chemical production, and the utilization of crops and wastes as sustainable energy sources. The United States had 2.06 million farms in 1997. Farms generating annual sales of $\$ 1,000$ or more of agricultural products are included in the census. The number of farms has declined annually by about 1\% from 1987 through 1997 for a total decline of approximately $7 \%$ for the period.

The amount of land used for farming continues to decline slowly; the total of 968 million acres in 1997 is down $0.2 \%$ from a year earlier and down $3.1 \%$ from 1987. Farmland has declined every year since reaching its peak at 1.206 billion acres in 1954 . The number of farms has declined at a faster rate than farmland with the average farm size increasing from 451 acres in 1987 to 471 acres in 1997. Total farm output for 1996 was $\$ 230$ million. About half of this total comes from harvested crops; $40 \%$ from meat, dairy, and poultry; and the remaining $10 \%$ from forestry and farm services.

Labor use on U.S. farms has changed dramatically over the past several decades. Average annual farm employment dropped from 9.9 million in 1950 to 2.9 million in 1997. This decrease resulted largely from the trend toward fewer and larger farms, increased farm mechanization and other technological innovations, and higher off-farm wages. However, farm employment appears to have stabilized in recent years as increases in mechanization and labor-saving technology have leveled off and the downward trend in farm numbers has slowed.

The agriculture industry consumed approximately one quad of energy in 1997 for operating farm equipment, fertilizer and pesticide application, irrigation, and transportation of products. Electricity is used for conveyors, irrigation systems, and specialized machinery such as milking machines. Diesel fuel is the primary energy source $(63 \%)$, followed by gasoline and liquefied gases. Farm fuel expenditures account for about $3.5 \%$ of total farm production expenses.

While agriculture is dependent on fossil fuel sources, many farms could benefit from the use of biofuels for farm machinery and vehicles and for generation of electricity. Biomass is also a suitable feed stock for 
industrial products such as chemicals and plastics. Farms also have opportunities to make greater use of renewable resources such as solar and wind energy.

Environmental factors are very important in the agricultural sector as indicated by the following statistics:

- Farms produce an estimated one billion tons of waste (including crop residues) annually.

- Farms produce an estimated one million gallons of liquid waste per day.

- Potential contamination of water supplies exists from animal waste, agricultural chemicals and fertilizers.

- The food processing industry produces an estimated six million metric tons of non-hazardous waste each year.

- The cost of pollution control and abatement for food processors is high, with \$275 million for capital equipment and \$1.45 billion in related operating costs in 1994.

\section{A.3 MINING}

The mining sector consists of industrial minerals, metallic minerals, and coal. These mining sectors and associated 1997 shipment values are as follows.

- Mining of industrial minerals, used in construction, agriculture and manufacturing had the highest shipment value totaling \$27.1 billion. Primary industrial mineral production includes kaolin (a specialty clay used in the production of paint and glossy paper), phosphate (agriculture), and salts, each having production values that exceed $\$ 1$ billion.

- Mining of metallic minerals equaled \$12.4 billion including copper, gold, zinc, and iron ore, each of which had shipment value in excess of $\$ 1$ billion. Other domestically produced metallic minerals with annual values approximating one-half billion dollars per year include lead, magnesium, and molybdenum.

- Coal mining had a total shipment value of $\$ 19.9$ billion. Low-cost coal and uranium generate over three-quarters of the nation's electricity, helping to keep U.S. electricity costs among the lowest in the world and thereby enhancing the competitiveness of U.S. industry.

The U.S. mining industry consumes about 2 quads of energy annually, approximately $3.2 \%$ of the total energy used by all U.S. industries. Energy costs are an important component to the mining industry and are estimated at about $5 \%$ of the overall shipment value. Significant efficiency gains could be obtained by improving mining operations through new exploration techniques, drilling, ventilation, and extraction technologies. Energy reduction can also be achieved through improved processing associated with grinding, crushing, milling, rolling, and smelting. Consuming less energy for mining and processing is a key objective for the mining industry.

\section{A.4 FOOD PROCESSING}

Of the selected industries, the food sector has the largest value of shipments of nearly $\$ 480$ billion. It is the second largest industry overall in the manufacturing sector, behind SIC 37, transportation equipment, which had shipments of $\$ 520$ billion in 1997. The United States has over 20,000 food-processing establishments, employing 1.6 million people. The food industry is not currently an IOF; however, it is included in this report because of its close relationship to the agricultural industry and its success with CHP. 
The food industry is an excellent candidate for CHP. The food industry had a peak steam draw of 53 million lb/h (Petroleum Information/Dwights 1998). The industry has many small operations that use packaged boilers producing $<25,000 \mathrm{lb} / \mathrm{h}$. The food industry spent more than $\$ 3.2$ billion for electricity in 1994 (DOE EIA 1994). The sector produces a huge variety of products with more than 50 four-digit SIC categories. Energy end use is primarily for material handling, cooking, freezing, and refrigeration. Almost half of all the energy input is used for generating steam.

\section{A.5 FOREST PRODUCTS}

Wood and paper industries provide materials essential for communication, education, packaging, construction, shelter, and sanitation. The United States produced 95 million tons of paper and paperboard in 1997, almost 739 pounds for every man, woman, and child. Forest products is also the third largest industrial consumer of energy, and generates more than 2 billion tons of waste each year-mostly in the form of nonhazardous wastewater and sludge. The industry generates 55\% of its own energy using wood waste and other renewable sources (bark, wood, and pulping liquor), often supplemented with natural gas. Since 1972, the industry has reduced consumption of fossil fuels by about $2 \%$ and purchased energy, while increasing total production by nearly 64\%. The industry cogenerated 59 billion kWh in 1994 (DOE EIA 1994) and spent more than $\$ 8.1$ billion on purchased fuels and electricity in 1996, or over $3 \%$ of its shipment value.

The paper and allied products industry group is represented by SIC 26. This industry processes wood, recycled paper, and cellulose fibers into a wide variety of paper, paperboard, and particleboard. The paper industry has three major subsectors, including pulp mills (SIC 2611), paper mills (SIC 2621), and paperboard mills (SIC 2631).

The paper industry ranks third in energy use among the IOF with a total consumption of 2.7 quads. Electricity accounted for 72 billion $\mathrm{kWh}$, costing $\$ 2.9$ billion. The industry strives to reduce its outside energy purchases and improve utilization of by-products, mainly black liquor, residues, as wood chips and other woody wastes known as "hog fuel." Of particular interest is the use of a black liquor gasifier in combination with a combined cycle gas turbine system.

The industry is a large consumer of steam. Steam is used for power generation (usually back pressure turbine) and process heating. Most pulp and paper processes require temperatures $<500^{\circ} \mathrm{F}$.

\section{A.6 CHEMICALS}

The chemical industry consists of more than 12,000 plants producing 70,000 different chemicals that provide the raw materials for industry, agriculture, construction, mining, and medicine. Chemical products can be grouped in three major categories:

- basic chemicals (e.g., acids, alkalis, salts, and organics)

- intermediate chemicals (e.g., synthetic fibers, plastic materials, and color pigments), and

- finished chemicals (e.g., paints, fertilizers, and explosives). 
In 1996 the U.S. chemical industry employed 1.03 million people; 58\% are production workers who earn one-third more than the manufacturing average. The industry had annual shipments of $\$ 372$ billion, including over $\$ 62$ billion in exports, accounting for $\$ 1$ of every $\$ 10$ of U.S. goods exported. The industry invested over $\$ 34$ billion in plant and equipment. Production is concentrated in Texas, Louisiana, the middle Atlantic states, and California. The chemical industry invested over $\$ 34$ billion on new plants and equipment and \$18.3 billion on research and development in 1996.

The petrochemical industry uses large quantities of fuels for chemical feedstocks in addition to fuel for heat and power. Energy consumption per unit of output has declined by over 39\% between 1974 and 1996.

Environmental issues and costs in the industry are a significant concern. Regulatory costs are growing faster than most other capital budget components; pollution abatement costs were over $\$ 4.6$ billion in 1994. This spending has resulted in decreased air emissions and a $61 \%$ decrease in toxic emissions between 1988 and 1994 during a period when production increased by $18 \%$.

\section{A.7 PETROLEUM REFINING}

Petroleum is the single largest source of energy for the U.S. economy. Measured in terms of energy content, the nation uses two times more petroleum than either coal or natural gas, and four times more petroleum than nuclear power, hydroelectricity, and other renewable energy sources. Most refineries in the United States are concentrated on the West and Gulf Coasts primarily because of proximity to oil wells and access to major sea transportation and shipping routes. The majority of oil distillation capacity is currently centered in large, integrated companies with multiple refining facilities. About $25 \%$ of all facilities are small operations producing fewer than 50,000 barrels per day, representing about $5 \%$ of the total output of petroleum products annually.

The supply of refined petroleum products has increased by more than 3 million barrels per day since 1970. In 1996, U.S. refiners supplied over 18 million barrels per day of refined petroleum products. U.S. refiners rely on both domestic and foreign producers for crude oil. Historical trends over the past ten years indicate imports of crude oil have been rising steadily.

\section{A.8 GLASS INDUSTRY}

The glass industry is a mature, capital and energy intensive industry that relies on raw materials, principally sand, limestone, and soda ash. The glass industry has evolved into four distinct segments:

- glass containers,

- fiberglass for insulation and structural applications,

- flat glass, and

- $\quad$ specialty glass such as tableware, light bulbs, television tubes, fiber optics, and scientific and medical equipment.

The glass industry is spread across the nation with workers concentrated in Ohio, Pennsylvania, California, North Carolina, Texas, Indiana, Michigan, New Jersey, New York, and Wisconsin. In 1997, the U.S. glass industry directly employed 150,400 people in the United States, where $82 \%$ are production workers who earn an average of $\$ 15.53$ per hour. The industry had shipments of about $\$ 27$ billion and spent over $\$ 1.9$ billion on new capital equipment. The industry spent about $\$ 1.4$ billion on fuel and energy, representing over $5 \%$ of its shipments' value. The glass industry uses in excess of 250 trillion Btu 
annually to produce approximately 21 million tons of glass products. Nearly $80 \%$ of this energy is supplied by natural gas with electricity accounting for most of the remainder.

\section{A.9 ALUMINUM INDUSTRY}

The U.S. aluminum industry is the largest in the world producing more than 22 billion pounds of metal annually worth approximately $\$ 35$ billion. Since 1987, the U.S. supply has increased at an average annual rate of $3.5 \%$. The aluminum industry impacts every state in the United States through plants and facilities, recycling, heavy industry, or consumption of consumer goods. Aluminum plants are located throughout the country but concentrations exist in the Pacific Northwest, the industrial Midwest, along the seaboard in the Northeast, and in the mid-South. Primary production is increasing, and recycling operations are increasing even faster. While aluminum continues to find new uses in industry (transportation infrastructures, electricity transmission, defense and aerospace, and packaging), aluminum must compete with other materials that offer cost and other competitive advantages. Innovation in research and development, as well as cost management are crucial to maintaining this industry's competitive edge.

During 1996, the industry employed over 143,000 people with an annual payroll of $\$ 4.8$ billion. Energy costs of about $\$ 2.6$ billion account for 20-30\% of the cost of primary aluminum production. Energy used in the production of aluminum represents about $1.8 \%$ of total U.S. industrial energy consumption.

The IOF technology roadmap adopted by the aluminum industry states that a $25 \%$ reduction in costs is one of its goals. Because energy represents a $\$ 2$ billion expenditure, nearly one-third the cost of aluminum, production costs are very sensitive to the cost of energy. Furthermore, the industry is striving to reduce electric consumption from the current U.S. average of $15.2 \mathrm{kWh} / \mathrm{kg}$ of aluminum to $13 \mathrm{kWh} / \mathrm{kg}$ in the near term and $11 \mathrm{kWh} / \mathrm{kg}$ in the long term. Because steam is used in the digestion phase of the Bayer process, opportunities for CHP exist that are specifically mentioned in the IOF technology roadmap.

\section{A.10 STEEL INDUSTRY}

Steel is the most basic and widely used metal in industry, and it is vital to the economic and national security of the United States. The steel industry is a $\$ 68.5$ billion industry employing over 210,000 workers and shipping nearly 80 million tons of steel per year. It is the fourth largest energy consuming industry in the United States. and generates 3 million tons of solid waste.

The industry converts iron ore or iron-bearing scrap into intermediate and finished steel products. The industry has been impacted by competition from other materials, other countries, and market changes in shipbuilding and automobiles. The industry has responded well to the changes and has adapted with new alloys and new process technologies. The industry has met the financial burden of complying with strict environmental regulations.

The industry consumed 1.7 quads of energy for heat and power in 1994, spending \$2.1 billion for electricity. The two major uses of electricity are machine drives and process heating. Machine drives include electric-' motor driven rolling mills and sometimes hydraulic presses used to forge steel and equipment used for material handling. The electric arc furnace is used for process heating. Overall, the industry is a large electric consumer with high peak loads. The cost of electricity is an important factor in siting new plants and plant expansions. 
Many facilities have central boiler plants, supplying steam for facility heating and process heating. Many of the larger boiler plants generate electricity using back-pressure steam turbines. Overall, the steel industry is not a large consumer of steam and so the prospects for CHP are modest.

The U.S. steel industry, accounting for about $8 \%$ of world wide steel production, competes in an environment where world capacity, some 900 million tons, exceeds actual annual production by nearly 200 million tons. Central to sustaining the industry's competitiveness are efforts to reduce costs and improve quality through fewer processing steps, higher yields, greater energy efficiency, and improved environmental performance.

\section{A.11 METALS CASTING}

The United States is the largest producer of metal casting products in the world. In 1997, the U.S. metal casting industry shipped over 14 million tons of castings with a value exceeding $\$ 22.7$ billion. Major enduse markets include all sectors of the U.S. economy and include motor vehicles and other transportation equipment, pipes, industrial machinery, construction materials, and aerospace. Castings of ferrous metals account for $85 \%$ of tonnage shipments and $61 \%$ of the shipments' value. Nonferrous castings, primarily aluminum, account for the remainder.

The industry employed nearly 217,000 people in over 3,100 foundries. The industry is dominated by small business. Nearly $80 \%$ of U.S. metal casters employ fewer than 100 people. Only $4 \%$ of businesses employed more than 250 persons. Metal casting is vulnerable to the cost of increasingly stringent environmental and occupational regulations that, along with changing market conditions and increased global competition, have resulted in the annual loss of about 100 metal casting establishments during the past two decades.

\section{A.12 ENERGY USE IN THE IOFS}

Figure A.2 shows energy consumption in the IOFs and food industry. These ten industries account for nearly $25 \%$ of total energy consumption in the United States. Key energy trends for the IOFs include the following:

- The petroleum refining industry consumed $29 \%$ of all energy used in the manufacturing sector. Half of this energy was used as feedstock rather than fuel to generate heat and power. Total energy consumption has decreased $2.3 \%$ per year, and average expenditures have decreased $2.7 \%$ per year. While total energy use has declined, consumption of natural gas has increased $0.9 \%$ per year between 1991 and 1994.

- The chemical industry consumed $25 \%$ of all energy used in the manufacturing sector. Nearly half of this energy was used as feedstock. Energy consumption has increased 6.7\% per year between 1991 and 1994. Consumption of purchased electricity increased by $6.2 \%$ per year; however, the cost of this electricity grew at only $3.7 \%$ per year.

- The paper industry consumed 12\% of the total manufacturing energy use. Between 1991 and 1994, purchased electricity increased $4.1 \%$ per year. Total energy expenditures increased at an average rate of $1.0 \%$ per year. 


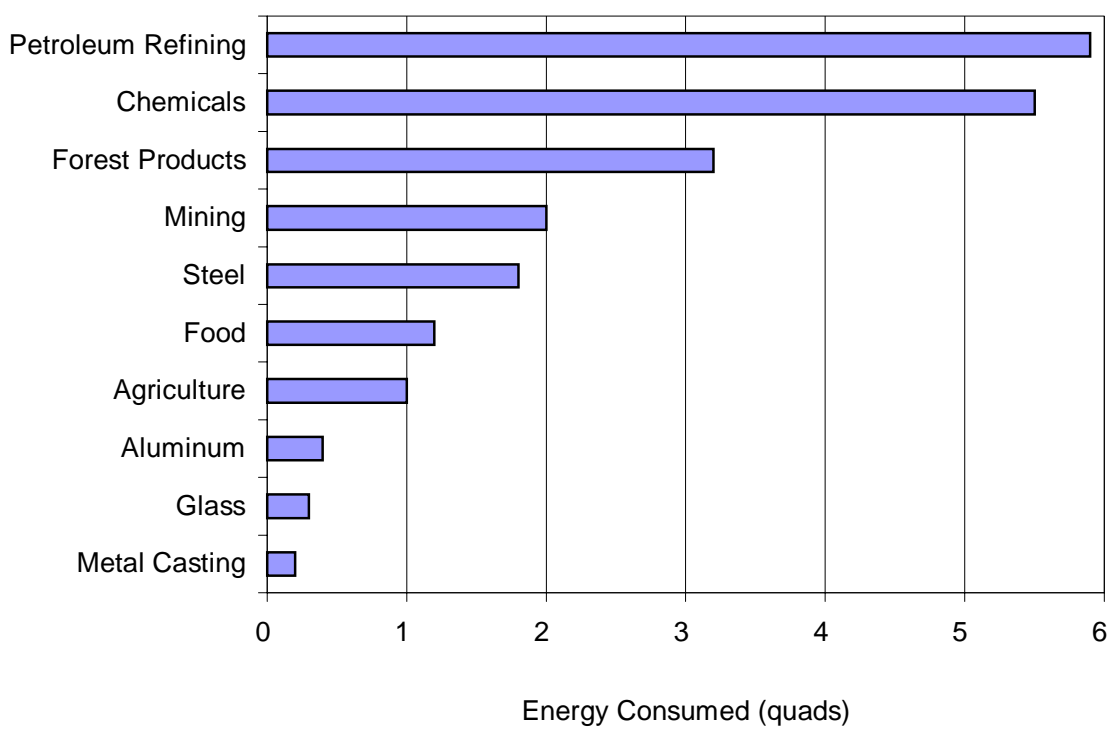

Fig. A.2. Total energy consumption.

- The primary metals industries consumed $11 \%$ of total manufacturing energy use. Almost $40 \%$ of the energy consumed was for feedstock, mostly as coke and breeze. Purchased coke and breeze has increased between 1991 and 1994 by $25.2 \%$ per year, representing the ongoing trend to reduce or eliminate coke production. Total energy expenditures have been increasing by $2.1 \%$ per year.

Natural gas, oil, and coal are used for process heating, feedstock and facility HVAC. Direct process heating is used for heating and melting furnaces, dryers, etc. Natural gas is preferred for direct process heating applications because of its clean combustion characteristics. Most processing heating is accomplished with steam generated in fossil-fueled boilers. Coal and residual oil are used for boiler fuel in many industries. These fuels produce higher environmental impacts and require higher investments for abatement. Most CHP systems produce steam or hot water and compete directly with purchased electricity and generated or purchased steam.

Figure A.3 shows the relative energy intensity for selected manufacturing activities within the IOFs.

Electricity is used primarily for machine drives and facility HVAC. Large quantities of electricity are used in process applications such as aluminum smelting and chlor-alkali production. Net electricity use in the IOFs accounts for $12 \%$ of the total energy used, according to MECS. This ranges from a high of $73 \%$ for the aluminum sector to a low of $<4 \%$ in the petroleum-refining sector. Electricity use is also important in the metal casting and chemical sectors, representing $32 \%$ and $16 \%$ of their total costs. Electricity for machine drives consumes $60 \%$ of the total used.

Table A. 2 shows consumption and cost for electric power and steam for the IOFs. Figure A.4 shows that the chemical industry consumes the most electricity and steam among the IOFs. Agriculture and mining were not included in the figure because data was not available. Steel, aluminum, and metal casting are represented together in Fig. A.4 as primary metals, SIC 33. The IOFs account for 58\% of total manufacturing electricity purchases and $80 \%$ of total steam produced from purchased fuels. The combined energy bill for steam and power in the manufacturing IOFs is $\$ 27.3$ billion. The chemical, paper, food, and refining industries are excellent candidates for CHP, all having large steam demands. 


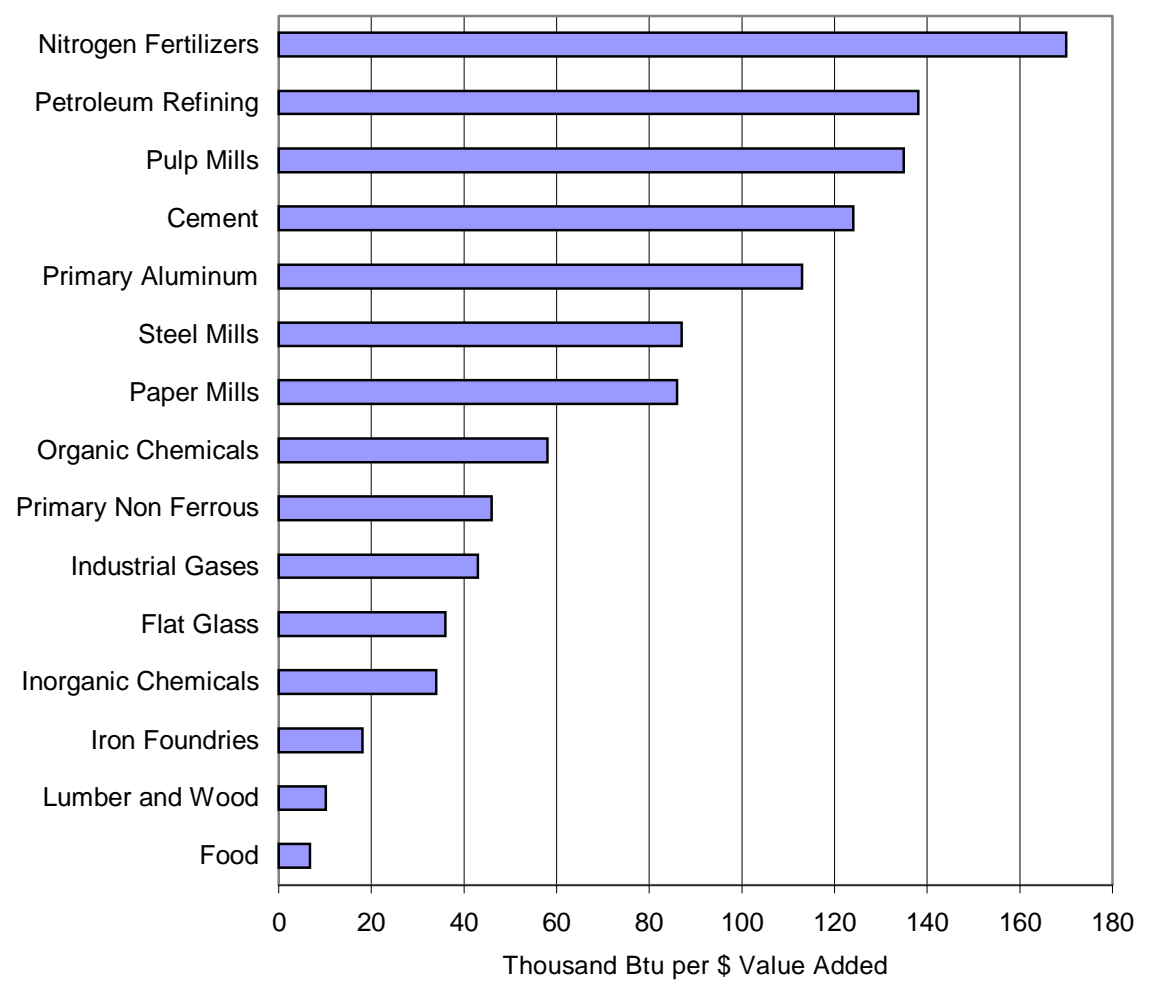

Fig. A.3. Energy intensity for selected activities.

Table A.2. Power and steam consumption

\begin{tabular}{clrcrc}
\hline \multirow{2}{*}{ SIC } & \multirow{2}{*}{ Industry } & \multicolumn{2}{c}{ Electricity } & \multicolumn{2}{c}{ Steam* } \\
\cline { 3 - 6 } & & Trillion Btu & $\$$ Millions & Trillion Btu & $\$$ Millions \\
\hline 20 & Food & 200 & $\$ 3,200$ & 570 & $\$ 1,300$ \\
24 & Lumber & 75 & $\$ 1,200$ & 20 & $\$ 80$ \\
26 & Paper & 250 & $\$ 3,000$ & 880 & $\$ 1,700$ \\
28 & Chemicals & 540 & $\$ 5,400$ & 1,200 & $\$ 2,500$ \\
29 & Oil refining & 120 & $\$ 1,500$ & 300 & $\$ 600$ \\
32 & Glass & 120 & $\$ 1,700$ & 210 & $\$ 70$ \\
33 & Primary metals & 480 & $\$ 4,800$ & 170 & $\$ 370$ \\
& $\quad$ Total IOF & 1,800 & $\$ 20,700$ & 3,200 & $\$ 6,700$ \\
$20-39$ & Total manufacturing & 2,700 & $\$ 36,000$ & 3,600 & $\$ 8,400$ \\
& IOF share & \multicolumn{5}{c}{$5 \%$} & $80 \%$ \\
\hline
\end{tabular}

* Energy for steam production is for purchased fuels only. An additional 882 trillion Btu in black liquor is used in the paper industry. Also, 951 trillion Btu of biomass and wastes are used, primarily in the paper and lumber industries.

Source: Energy Information Administration. 1994. Manufacturing Energy Consumption Survey. 


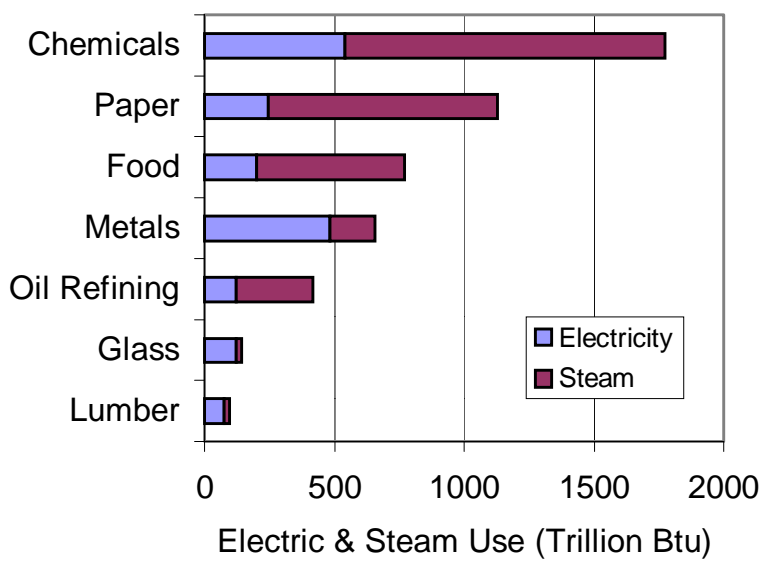

Fig. A.4. Steam and power use.

\section{A.13 EXISTING CHP IN THE IOFS}

More than 45,000 MW of installed CHP capacity, generating 142 billion kWh, represent over $15 \%$ of total industrial requirements. Table A.3 shows the breakdown for the IOFs in the manufacturing sector based on data from the 1994 MECS. Data for the glass industry was not available. The IOFs account for $94 \%$ of the total electricity that is generated from industrial sources. The paper and chemical industries account for nearly $75 \%$ of the total production.

Table A.3. Components of net electrical requirements

\begin{tabular}{clrrrr}
\hline \multirow{2}{*}{ SIC } & \multicolumn{1}{c}{ Industry } & $\begin{array}{c}\text { Purchases/ } \\
\text { transfers }\end{array}$ & $\begin{array}{c}\text { On-site } \\
\text { generation }\end{array}$ & $\begin{array}{c}\text { Transfers } \\
\text { out }\end{array}$ & $\begin{array}{c}\text { Net } \\
\text { requirements }\end{array}$ \\
\cline { 3 - 6 } & & \multicolumn{4}{c}{$($ million $\mathrm{kWh})$} \\
\hline 20 & Food & 59,700 & 7,000 & 1,800 & 64,900 \\
24 & Lumber & 20,800 & 2,000 & 1,000 & 21,800 \\
26 & Paper & 72,200 & 58,800 & 9,300 & 122,000 \\
28 & Chemicals & 160,000 & 46,800 & 7,700 & 199,000 \\
2911 & Petroleum refining & 34,800 & 13,800 & 1,400 & 47,200 \\
33 & Primary metals & 55,200 & 4,800 & Net & 60,000 \\
& Total IOF & 403,000 & 133,000 & 21,200 & 515,000 \\
$20-39$ & Total manufacturing & 804,000 & 143,000 & 28,200 & 918,000 \\
& IOF share & $50 \%$ & $94 \%$ & $75 \%$ & $56 \%$ \\
\hline
\end{tabular}

Figure A.5 sorts the installed CHP capacity by industry sector. Total CHP capacity in the IOFs is over $42,000 \mathrm{MW}$, representing $87 \%$ of the total CHP capacity in all agriculture, mining, construction, and manufacturing sectors. The same information is presented in Table A.4.

Table A.5 shows CHP fuel type for the IOFs based on 1999 data. Installations are dominated by natural gas, representing the primary fuel source for $61 \%$ of installations. As shown in the table, other fuels are important in specific applications. 


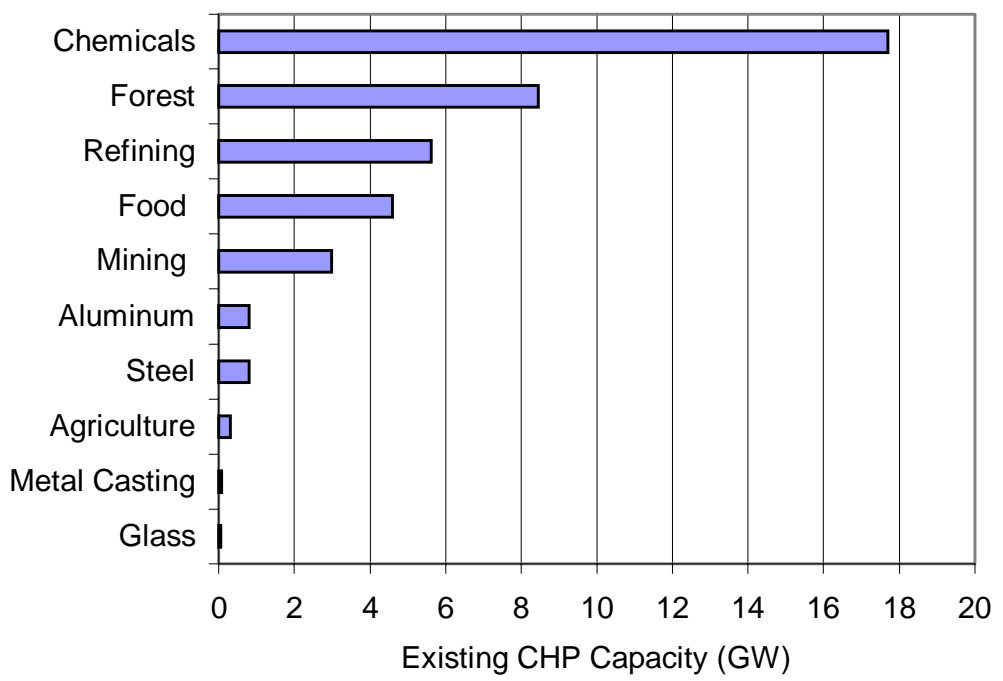

Fig. A.5. Existing CHP capacity.

Table A.4. 1999 operating CHP capacity

\begin{tabular}{|c|c|c|c|c|c|}
\hline SIC & Industry segment & $\begin{array}{c}\text { Existing CHP } \\
\text { capacity } \\
(\mathrm{MW})\end{array}$ & SIC & Industry segment & $\begin{array}{c}\text { Existing CHP } \\
\text { capacity } \\
(\mathrm{MW})\end{array}$ \\
\hline \multirow[t]{2}{*}{$1-7$} & Agriculture & 750 & & Glass & \\
\hline & Mining & & 3211 & Flat glass & 50 \\
\hline 10 & Metal mining & 120 & 3229 & Pressed and blown glass & 80 \\
\hline 12 & Coal mining & 250 & & Total & 130 \\
\hline \multirow[t]{2}{*}{14} & Nonmetallic minerals & 120 & 331 & Steel & 1,000 \\
\hline & Total & 490 & & Aluminum & \\
\hline \multirow[t]{2}{*}{20} & Food & 4,700 & 3341 & Secondary smelting & 800 \\
\hline & Forest products & & 3353 & Sheet, plate, and foil & 1,000 \\
\hline 24 & Lumber and wood & 800 & & Total & 1,800 \\
\hline \multirow[t]{2}{*}{26} & Paper & 8,600 & & Metal casting & \\
\hline & Total & 9,300 & 3322 & Malleable iron foundries & 0.1 \\
\hline 28 & Chemicals & 17,700 & & Total & 0.1 \\
\hline \multirow[t]{4}{*}{2911} & Petroleum refining & 5,600 & & & \\
\hline & IOF total & & & & 41,500 \\
\hline & Total industrial & & & & 48,000 \\
\hline & IOF share & & & & $86 \%$ \\
\hline
\end{tabular}

Source: Hagler-Bailly Independent Power Database with adjustments by OEC. 
Table A.5. CHP fuel type in the IOFs

\begin{tabular}{|c|c|c|c|}
\hline Fuel type & $\begin{array}{l}\text { Existing CHP } \\
\text { capacity } \\
\text { (MW) }\end{array}$ & Share & Description \\
\hline Natural gas & 25,400 & $61.3 \%$ & $\begin{array}{l}\text { Most widely used fuel with broad application in all } \\
\text { industries }\end{array}$ \\
\hline Coal & 6,600 & $15.8 \%$ & $\begin{array}{l}\text { Widely distributed but with higher concentrations in } \\
\text { agriculture, mining, paper, and primary metals }\end{array}$ \\
\hline Oil & 1,100 & $2.6 \%$ & $60 \%$ used in petroleum refining \\
\hline Wood & 2,300 & $5.6 \%$ & $94 \%$ used in forest products \\
\hline Black liquor & 2,200 & $5.2 \%$ & Used solely in the paper industry \\
\hline Waste energy & 700 & $1.8 \%$ & $\begin{array}{l}\text { By-product of sulfuric acid manufacture and refining } \\
\text { and steel industries }\end{array}$ \\
\hline Waste fuels & 2,900 & $6.9 \%$ & $\begin{array}{l}\text { Coal wastes, refinery gas, petroleum coke, mine gas, } \\
\text { coke oven gas }\end{array}$ \\
\hline Agricultural waste & 200 & $0.5 \%$ & $88 \%$ used in food industry the rest in agriculture \\
\hline Renewable waste & 130 & $0.3 \%$ & $\begin{array}{l}\text { Bio-methane, municipal solid waste, more important } \\
\text { in municipal applications }\end{array}$ \\
\hline Total IOF & 41,500 & & \\
\hline
\end{tabular}

Approximately $85 \%$ of CHP systems in the IOFs use combined cycle and steam turbines, as shown in Fig. A.6. Approximately 22\% of CHP installations have capacities of $50 \mathrm{MW}$ and greater that account for almost $75 \%$ of the total existing CHP capacity. Approximately $28 \%$ of existing CHP installations in the IOFs are smaller than $4 \mathrm{MW}$; however, these sites account for only $2 \%$ of the capacity.

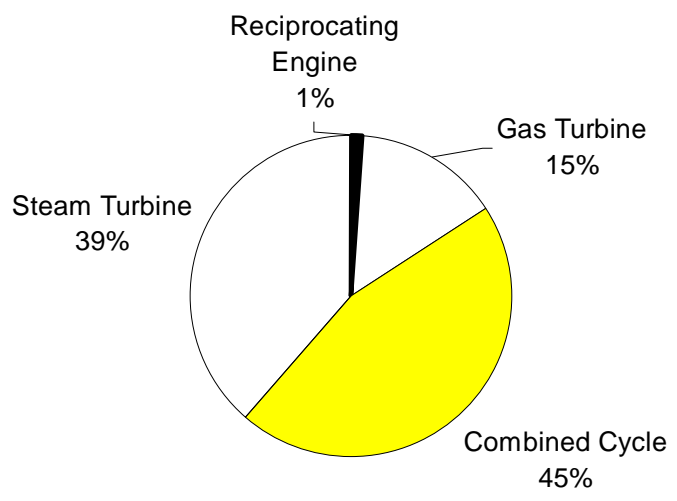

Fig. A.6. CHP system types for the IOFs. 


\section{APPENDIX B \\ IMPACT OF ELECTRIC INDUSTRY RESTRUCTURING ON THE IOFs}

\section{B.1 IMPACTS OF RESTRUCTURING ON INDUSTRY}

The majority of industrial customers have secured electricity price reductions during the 1990s, with many paying retail prices that approach wholesale electricity prices for firm power. From 1992 through 1996, the national average electricity price for the industrial sector declined from 4.8 to 4.6 cents $/ \mathrm{kWh}$. During this same period, residential prices rose from 8.4 to 8.6 cents $/ \mathrm{kWh}$. These changes followed the passage of the Energy Policy Act of 1992 that created a competitive market for wholesale power that began to exert a downward pressure on prices (DOE EIA 1998). Industrial and large commercial customers had enough market power to achieve concessions from posted utility prices. Smaller customers, however, remained captive to prices that were based on past utility investments-not on the current competitive levels. As a result, several states began to initiate electric industry restructuring that would bring competition and retail access to a broader range of customers. Continued implementation of both wholesale and retail electric industry restructuring will create new opportunities and challenges for industrial power consumers.

The following characteristics of the existing power market highlight the need for competitive restructuring.

\section{B.1.1 Regional Price Variability}

A wide variation of electric prices exists across the country. The geographical variation is shown in Fig. B.1. The high-cost regions are in New England, the Northeast, and California. Prices are also moderately high in the industrialized east-north-central region.

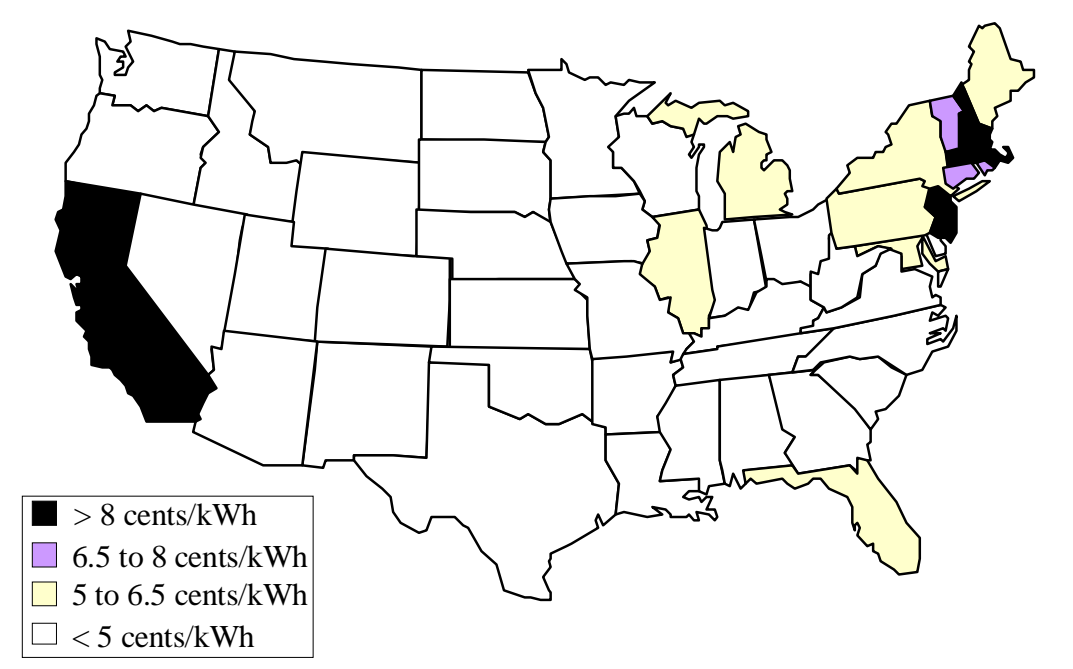

Fig. B.1. Regional variation in average industrial electricity prices. 


\section{B.1.2 Customer Class Variability}

Within the current regulated structure of the electric power industry, a wide variability of prices exist both between customer classes and also between individual customers within the same class and served by the same utility. The median commercial customer rates $(7.24$ cents $/ \mathrm{kWh})$ are $75 \%$ higher than the median industrial rates (4.14 cents/kWh). Even within the industrial sector, variation often exists based on the industry's place in a regional economy and its ability to negotiate with the utility. For example, in 1994, manufacturers in the paper industry paid an average of 2.9 cents $/ \mathrm{kWh}$ in the Mountain Census Region; whereas, manufacturers in the chemical industry paid an average of 4 cents/kWh. The practice of applying selective rate discounts to customers that threatened to remove load by generating their own electricity was very common in the regulated industry. These so-called economic deferral rates have exerted a strong negative effect on customer generation projects. Restructuring could create a more uniform price for power in the United States and help to bring competitive rates into the current high-cost areas.

\section{B.1.3 Noncompetitive Assets}

A primary cause of regional price disparity is utility imbedded costs that are too high to be recovered in today's competitive market. By addressing stranded assets, restructuring plans will preserve the financial integrity of the power supply industry and thereby minimize economic disruptions in the industry that would interfere with an orderly transition to a competitive market for power. These transition rules may inhibit industrial generation projects during the transition period. In some cases, niche opportunities may exist for on-site generation that meets specific requirements, such as size, ownership, fuel type, or overall efficiency.

Electric industry restructuring is expected to provide many benefits. Lower prices will be available to more classes of customers. Lower power costs will help some industries to maintain their competitiveness both in the United States and globally. However, the large industrial customers, especially those that rely on huge quantities of electricity for production, may not see much additional reduction in the average price paid for electricity and could, in fact, have somewhat higher prices because of the increased retail access to low-cost power sources. Both large and small customers will have greater flexibility in choosing their supply and service options. Restructuring is also expected to lift many of the restrictions that utilities currently impose on customer generation of power. Efforts are under way to standardize interconnection rules and to liberalize backup power contracts and terms for wheeling power.

Industry will also face new challenges. Optimizing the overall energy needs of a facility will become more complex with multiple supply options, backup sources, hedging and other risk management strategies. Municipal utilities and large industrial customers are concerned that the utility system will become less reliable. This concern for reliability includes the possibilities of blackouts and brownouts during peak periods and for the possibility of extreme price volatility that could jeopardize an industrial concern's bottom line in a matter of hours. Power quality is also a concern because of the increasingly sensitive electronic equipment used in the industrial sector. Challenges for facilities with existing on-site generation may include pressure to renegotiate existing power contracts. Industries may need to reoptimize the role of existing power into the facility's and the system's overall needs. Customers with economic opportunities to implement new on-site generation projects may be locked out in some states by competition transition charges, exit fees, or other rules designed to provide equitable repayment of stranded assets. 


\section{B.2 A NEW ROLE FOR ON-SITE GENERATION}

Competition has brought a greater awareness that electric service is a bundle of services that can be provided and priced separately (i.e., unbundled) in a competitive market. If individual services are not separately priced or if there is cross-subsidization of one customer class to another-it creates an opportunity for new competitors to take profitable businesses and leave the utility with unprofitable businesses. The individual services provided can be described as follows:

- Energy-providing all the customer's kilowatt-hours.

- Capacity-meeting the customer's peak load requirements.

- Reserve-maintaining additional capacity for fluctuations and emergencies.

- Reliability-the end result of the level of investment in facilities and labor and management.

- Power quality-voltage and frequency support and reactive power.

- Backup and standby service-support for customers with partial generating capability.

As customers and energy service providers develop the freedom to contract separately for these individual services, industrial customers may have a greater opportunity to use distributed generation as a means to optimize the sum of services required.

On-site generation can be designed to meet a wide variety of service requirements and fulfill the needs of many customers and energy service providers. The applications defined below represent typical services and benefits provided by on-site generation.

\section{B.2.1 Combined Heat and Power}

Combined heat and power (CHP) is already a major technology in the industrial sector as the focus of this analysis shows. The application of CHP was greatly expanded by the Public Utilities Regulatory Policy Act of 1978 (PURPA). In the past twenty years, >40,000 MW of CHP capacity has been built. The cogeneration rules in PURPA were designed to increase efficiency of fossil fuel usage and stimulate the market by requiring utilities to interconnect with cogenerators and buy power at avoided costs that were calculated according to regulated procedures. In a competitive power market, more flexible rules will be required to ensure that customers, developers, and utilities can negotiate appropriate relationships that optimize the benefits of CHP for each of the participants. In addition, CHP can provide social benefits in the form of overall reduction of air and water pollution, reduction of emissions of greenhouse gases that contribute to global warming, and development of local and regional economies. CHP is the primary focus for power generation in the industrial sector because this sector's characteristic large thermal loads can be handled efficiently with environmental and social benefits. Some examples of modern CHP plants within the industrial sector include the following.

KMS Energy sited an 8-MW CHP facility that provides all electricity and up to $80 \%$ of the thermal energy needs for Eagle Gypsum Products in Colorado. Built in just 7 months, the facility uses two Allison 501-KB5 gas turbines to generate prime power. Two Detroit Diesel reciprocating engines provide backup and supplemental electricity. About $60 \mathrm{MMBtu} / \mathrm{h}$ is recovered from turbine exhaust gas that is used directly to dry the gypsum board. The CHP system features a permissive start system to control the start up of multiple 400-hp motors in the board plant and a load-shedding system to reduce noncritical loads in the event of a generator overload or an unplanned outage. Because of close proximity to residential areas, noise abatement was a major design parameter for the system. In addition to reducing energy costs, the system increases overall reliability of plant operation. 
In another KMS-owned project, Entenmanns' Bakery in Northlake, Illinois, a 1.6-MW CHP facility meets the base-load electricity requirements. Two Caterpillar natural gas-fueled reciprocating engines operate in parallel with the electric utility that provides supplemental, maintenance, and backup power.

Approximately $7 \mathrm{MMBtu} / \mathrm{h}$ of heat is recovered from engine jacket water and exhaust and is used for process and sanitation. The CHP facility is operated and maintained by KMS, thereby freeing the bakery from the need to hire, train, and maintain staff.

Teco Energy Systems owns and operates Pasco Cogen, Ltd., a Florida limited partnership that owns a 109-MW natural gas-fired, combined-cycle cogeneration facility located adjacent to the Lykes Pasco Citrus Processing Plant, in Dade City, Florida. The facility is interconnected to the Florida Power Corporation's transmission system and sells electricity to the utility under a 20-year power purchase agreement. In addition, the facility sells steam to Lykes Pasco, Inc. The CHP system consists of two General Electric LM 6000 combustion-turbine generator packages, two heat recovery steam generators, a steam turbine generator, and accompanying steam and condensate return facilities. In this case, the industrial facility continues to purchase electricity from the utility, but purchases steam from the CHP facility.

\section{B.2.2 Standby Power}

The electric power system in the United States is extremely reliable. Customers rely on uninterrupted electric service. Outages do occur, most of which are the result of storm or accident damage to overhead transmission and distribution (T\&D) systems. With few exceptions, such outages tend to be brief and infrequent. Nevertheless, some customers are so sensitive to outages that they have on-site standby generators to supply power until utility service is restored. Some standby generators are required by law to maintain public health and safety, such as for hospitals, elevators, and water pumping stations. For other customers like telecommunications, retail, and process industries, the installation of standby generators is an economic choice based on extremely high outage costs.

Standby generators are not operated very frequently and are generally isolated from the grid. Approximately 40,000 MW of standby capacity is installed today. Some utilities recruit customers with standby generation for peak load reduction programs, offering payments or rate relief for limited operation during utility peak periods, generally fewer than 150 hours per year.

Customer choice of competitive power suppliers may stimulate the economic competitiveness of standby generators and increase the run hours for units in the field. Standby generation can be part of an optimal strategy that minimizes power costs and maximizes reliability through combinations of firm and interruptible power and on-site standby capability.

\section{B.2.3 Peak-Shaving}

The costs for power vary hour-by-hour depending on the demand and the availability of generating assets. Larger customers often pay time-of-use (TOU) rates that convert these hourly variations into seasonal and daily categories such as on-peak, off-peak, or shoulder rates. With the advent of wholesale and retail competition in certain markets, more of these cost variations will be transmitted directly as price signals. Both TOU customers and those participating in competitive power markets may consider on-site generation during high-cost peak periods. Using on-site generation for peak shaving could reduce the customer's overall cost of power. In turn, this customer capability could reduce the need for the energy service provider to generate or contract to receive and redistribute very high-cost power. TOU customers 
may find that their on-site generation systems are cheaper than the peak TOU rates for much of the year. The closer that the price paid for power matches the actual hourly costs, the greater is the economic benefits to both the customer and the energy service provider in developing a peak-shaving strategy.

Industrial facilities with large peak electric loads such as steel mini-mills or refrigeration facilities, will have a greater motivation to implement a peak-shaving strategy as the range between peak and off-peak prices widens. Two examples of industrial peak shaving are described below:

- Castle Metal Finishing Corp. in Schiller Park, Illinois has a 270-kW peak-shaving facility. The facility consists of a single Caterpillar Model 3408 natural gas-fired reciprocating engine. The generator operates isolated from the utility during peak electrical usage hours and for standby emergency services. A manual transfer switch is used to connect either the utility or the generator to Castle's electric load. The simplicity of the system allows Castle's own employees to operate the facility.

- Navistar International has a 9.2-MW peak-shaving facility at its diesel engine plant in Melrose Park, Illinois. The system consists of 12 Caterpillar 3516 turbocharged gas engines. The system operates in parallel with the local utility, Commonwealth Edison. The system is also capable of black start and grid-independent operation. During the not infrequent summer thunderstorms in the area, the system is disconnected from the grid to provide increased reliability in the event of a lightning-induced grid power outage. Half of the engines have heat recovery to produce $30-\mathrm{lb}$ steam for the plant. The system combines unique aspects of CHP, peak shaving, and reliability enhancement. Built for about $\$ 8$ million, the system provides approximately $\$ 2$ million per year in reduced energy costs.

\section{B.2.4 Grid Support}

The power grid is an integrated system consisting of generation, high-voltage transmission, substations, and local distribution. Selected use of distributed generation can provide system benefits and reduce the need for investment in other parts of the system. Potential distributed generation benefits include:

- emissions reduction for PV, fuel cells, and clean CHP;

- voltage and frequency support to enhance reliability;

- $\quad$ avoidance or deferral of high-cost, high lead-time T\&D system upgrades;

- reduction of line losses and reactive power control;

- transmission capacity release;

- reduced central generating station reserve requirements; and

- fuel use reductions when solar, renewable, or high efficiency distributed generation is applied in place of central station power.

The evaluation of these benefits and the development of mechanisms whereby distributed generation can provide grid support are ongoing processes. Industrial facilities can provide grid support benefits and defer costly system expansion through the use of distributed generation. Many existing CHP, peakshaving, or standby facilities may provide such benefits already. However, typically, these benefits are not explicitly compensated. In a restructured electricity industry, markets will develop for these gridsupport services, thereby providing additional financial incentives to customer power-generation projects. 


\section{B.2.5 Stand Alone (Grid Isolated)}

In selected situations, grid isolated distributed generation may be more economic than integration with the power grid. This would be true in very isolated or remote applications such as the 1.6 MW diesel engine prime power facility that McGowan Broz. Engineering installed for Alyeska Seafoods in remote Dutch Harbor, Alaska. In some cases, customers with CHP have separated from the grid due to an inability to negotiate economic backup power from their energy service provider. Competitive power access is expected to reduce the need for this second type of customer to isolate from the grid. There are applications, particularly in the mining industry, where a grid-isolated strategy may be preferable to extending a transmission line. 


\section{APPENDIX C ON-SITE GENERATION TECHNOLOGIES}

This section describes the distributed generation technology and the key characteristics of industrial applications that determine the optimal system configuration.

\section{C.1 ON-SITE GENERATION TECHNOLOGIES}

CHP and other on-site power systems are complex integrated systems that consist of a number of individual components, including fuel treatment, combustion, mechanical energy, electric energy, electricity conditioning, heat recovery, and heat rejection systems. However, CHP systems are typically identified by the prime mover that drives the overall system. Table C.1 compares key characteristics of the different technologies for CHP.

\section{C.1.1 Reciprocating Engines}

Reciprocating engines are among the most widely used and most efficient prime movers used in CHP systems. Electric efficiencies of 25-50\% make reciprocating engines an economic CHP option in many applications. The two most common types of reciprocating engines are (1) spark-ignited engines, usually fired with natural gas (Otto cycle) and (2) compression-ignited (diesel cycle) engines, fired with diesel fuel, heavy oil, or a combination of oil and gas. Engines can range in size from a few kilowatts to very large engines with capacities of several megawatts. Engine systems are appropriate for small applications of $<1 \mathrm{MW}$ to multi-megawatt systems that are designed around multiple engines. Engines systems are appropriate for backup and peaking because of their quick-start and load-following capability. They are also appropriate for smaller process industries such as manufacturing, fabrication, and food, which require heat in the form of hot water or low-pressure steam.

\section{C.1.2 Steam Turbines}

Steam turbines are one of the most versatile and oldest prime mover technologies used to drive a generator or mechanical machinery. Steam turbines are widely used for CHP applications in the United States and Europe where special designs have been developed to maximize efficient steam usage. A steam turbine is captive to a separate heat source and does not directly convert a fuel source to electric energy. Steam turbines require a source of high-pressure steam that is produced in a boiler or heat recovery steam generator (HRSG). Boiler fuels can include fossil fuels such as coal, oil and natural gas, or renewable fuels such as wood or municipal waste. These systems are widely used in the forest products industries often using wood waste as fuel.

\section{C.1.3 Gas Turbines}

Gas turbines (or combustion turbines) use the expansion of hot combustion gases to drive the rotating power turbine section which in turn powers the air compressor and the electric generator. The compressed air is mixed with fuel that is combusted to high temperatures to drive the power turbine. Continuous technical innovation has made gas turbines a very compact and efficient prime mover for power generation. The most common fuel source for gas turbines is natural gas, though a broad range of gaseous and liquid fuels can also be used. Gas turbines represented only $20 \%$ of the power generation market twenty years ago; they now claim approximately $40 \%$ of new capacity additions. Gas turbines are the most common CHP technology in the industrial 
Table C.1. Comparison of on-site generation technologies

\begin{tabular}{|c|c|c|c|c|c|c|}
\hline Characteristic & Diesel engine & $\begin{array}{c}\text { Natural gas } \\
\text { engine }\end{array}$ & Steam turbine & Gas turbine & Micro- turbine & Fuel cells \\
\hline $\begin{array}{l}\text { Electric } \\
\text { efficiency } \\
\text { (LHV) }\end{array}$ & $30-50 \%$ & $25-45 \%$ & $15-35 \%$ & $\begin{array}{c}25-40 \% \\
\text { (simple) } \\
40-60 \% \\
\text { (combined) }\end{array}$ & $20-30 \%$ & $40-70 \%$ \\
\hline Size (MW) & $0.05-5$ & $0.05-5$ & Any & $3-200$ & $0.025-0.25$ & $0.2-2$ \\
\hline $\begin{array}{l}\text { Footprint } \\
\left(\mathrm{ft}^{2} / \mathrm{kW}\right)\end{array}$ & 0.22 & $0.22-0.31$ & $<0.1$ & $0.02-0.61$ & $0.15-1.5$ & $0.6-4$ \\
\hline $\begin{array}{l}\text { CHP installed } \\
\text { cost }(\$ / \mathrm{kW})\end{array}$ & $800-1500$ & $800-1500$ & $800-1000$ & $700-1200$ & $500-1600$ & $>3000$ \\
\hline $\begin{array}{l}\text { O\&M cost } \\
(\$ / \mathrm{kWh})\end{array}$ & $0.005-0.008$ & $0.007-0.015$ & 0.004 & $0.002-0.008$ & $0.002-0.01$ & $0.003-0.015$ \\
\hline Availability & $90-95 \%$ & $92-97 \%$ & Near $100 \%$ & 90-98\% & 90-98\% & $>95 \%$ \\
\hline $\begin{array}{l}\text { Hours between } \\
\text { overhauls }\end{array}$ & $25,000-30,000$ & $24,000-60,000$ & $>50,000$ & $30,000-50,000$ & $5,000-40,000$ & $10,000-40,000$ \\
\hline Start-up time & $10 \mathrm{~s}$ & $10 \mathrm{~s}$ & $1 \mathrm{~h}-1$ day & $10 \mathrm{~min}-1 \mathrm{~h}$ & $60 \mathrm{~s}$ & 3 h-2 days \\
\hline $\begin{array}{l}\text { Fuel pressure } \\
\text { (psi) }\end{array}$ & $\begin{array}{l}<5 \text { (integral } \\
\text { fuel pump) }\end{array}$ & $1-45$ & n.a. & $\begin{array}{l}\text { 120-500 may } \\
\text { require } \\
\text { compressor }\end{array}$ & $\begin{array}{l}40-100 \text { may } \\
\text { require } \\
\text { compressor }\end{array}$ & $0.5-45$ \\
\hline Fuels & $\begin{array}{l}\text { Diesel, } \\
\text { residual oil, } \\
\text { diesel/gas } \\
\text { mixtures }\end{array}$ & $\begin{array}{l}\text { Natural gas, } \\
\text { biogas, } \\
\text { propane }\end{array}$ & All & $\begin{array}{l}\text { Natural gas, } \\
\text { biogas, } \\
\text { propane, } \\
\text { distillate oil }\end{array}$ & $\begin{array}{l}\text { Natural gas, } \\
\text { biogas, } \\
\text { propane, } \\
\text { distillate oil }\end{array}$ & $\begin{array}{l}\text { Hydrogen, } \\
\text { natural gas, } \\
\text { propane }\end{array}$ \\
\hline Noise & $\begin{array}{l}\text { Moderate to } \\
\text { high (requires } \\
\text { building } \\
\text { enclosure) }\end{array}$ & $\begin{array}{l}\text { Moderate to } \\
\text { high (requires } \\
\text { building } \\
\text { enclosure) }\end{array}$ & $\begin{array}{l}\text { Moderate to } \\
\text { high (requires } \\
\text { building } \\
\text { enclosure) }\end{array}$ & $\begin{array}{c}\text { Moderate } \\
\text { (enclosure } \\
\text { supplied with } \\
\text { unit) }\end{array}$ & $\begin{array}{l}\text { Moderate } \\
\text { (enclosure } \\
\text { supplied with } \\
\text { unit) }\end{array}$ & $\begin{array}{l}\text { Low (no } \\
\text { enclosure } \\
\text { required) }\end{array}$ \\
\hline $\begin{array}{l}\mathrm{NO}_{\mathrm{x}} \text { emissions } \\
(\mathrm{lb} / \mathrm{MWh})\end{array}$ & 3-33 & $2.2-28$ & 1.8 & $0.3-4$ & $0.4-2.2$ & $<0.02$ \\
\hline $\begin{array}{l}\text { Uses for heat } \\
\text { recovery }\end{array}$ & $\begin{array}{l}\text { Hot water, LP } \\
\text { steam, district } \\
\text { heating }\end{array}$ & $\begin{array}{l}\text { Hot water, LP } \\
\text { steam, district } \\
\text { heating }\end{array}$ & $\begin{array}{l}\text { LP-HP } \\
\text { steam, } \\
\text { district } \\
\text { heating }\end{array}$ & $\begin{array}{l}\text { Direct heat, hot } \\
\text { water, LP-HP } \\
\text { steam, district } \\
\text { heating }\end{array}$ & $\begin{array}{l}\text { Direct heat, } \\
\text { hot water, LP } \\
\text { steam }\end{array}$ & $\begin{array}{c}\text { Hot water, LP- } \\
\text { HP steam }\end{array}$ \\
\hline $\begin{array}{l}\text { CHP output } \\
\text { (Btu/kWh) }\end{array}$ & 3,400 & $1,000-5,000$ & n.a. & $3,400-12,000$ & $4,000-15,000$ & $500-3,700$ \\
\hline $\begin{array}{l}\text { Useable temp } \\
\text { for CHP }(F)\end{array}$ & $180-900$ & $300-500$ & n.a. & $500-1,100$ & $400-650$ & $140-700$ \\
\hline
\end{tabular}

sector. They are economic in sizes from one to several hundred megawatts, and they produce hightemperature, high-pressure steam needed by process industries.

Combined cycle plants are combustion turbines that use the heat energy contained in the exhaust to produce steam that in turn is used to drive a steam turbine. Combined cycle plants usually are over $100 \mathrm{MW}$ but systems as small as $8 \mathrm{MW}$ are available commercially. Combined cycle systems have electrical generation efficiencies approaching $60 \%$ in the largest systems. These systems are utilized in very large process oriented industrial facilities. These large facilities often are owned and developed by third parties providing contract or merchant power and steam to an industrial facility or complex. 


\section{C.1.4 Microturbines}

Microturbines are very small combustion turbines sized from 30-250 kW. Microturbines more closely resemble automobile and truck turbochargers than gas turbines. Most, though not all, microturbines operate at very high speed $(70,000-100,000 \mathrm{rpm})$ driving a high-speed generator. This high-frequency power must then be rectified and inverted to $60 \mathrm{~Hz}$ using complex power electronics gear. Several companies are developing microturbine systems that are now becoming available on the commercial market. Microturbines may be able to penetrate the very small end of the industrial market. If so, this would represent an incremental industrial market for on-site generation.

\section{C.1.5 Fuel Cells}

Fuel cells convert a chemical fuel directly into electricity in a manner analogous to a chemical storage battery except the chemical input is fed continuously into the cell. The chemical input to the cell is in the form of hydrogen and oxygen. Several types of fuels can be used as the hydrogen source for these systems through a process called reforming. Fuel cells are an emerging technology. Limited commercial application are in development of fuel cells for CHP and several additional fuel cell technologies. Fuel cells are inherently efficient and clean; however, their high cost precludes their use in most on-site generation applications. Fuel cells are finding a small niche market in smaller applications with high power costs, severe environmental constraints, and high power quality requirements.

\section{C.2 SYSTEM ISSUES}

Integrating on-site generation with a specific industrial application requires an understanding of the engineering and site-specific criteria that will provide the most economic solution. The electric and thermal load profiles of the facility are the key to designing an appropriate system. Additional factors such as power quality requirements, outage costs and the need for reliability, and the temperature and pressure requirements for the process heat are also important to determine the size of the system, the appropriate generating and heat recovery technologies, and the necessary subsystems. Electricity tariffs and fuel costs and availability at the site can affect design considerations, dictate optimal operating strategies, and determine the economic value to the customer. The final design must address siting issues such as equipment and facility environmental requirements, noise abatement and footprint constraints, and impact on the utility system. This section reviews some of the primary issues that design engineers face in selecting and designing an industrial CHP system.

\section{C.2.1 Electric and Thermal Load Profiles}

One of the first and most important elements in the analysis of CHP feasibility is obtaining accurate representations of electric and thermal loads. The economics of the system depend on the hour-by-hour electric and thermal loads that are met and the costs associated with meeting them. Economies of scale for CHP systems make larger systems generally lower in capital and operating cost than smaller systems. Several site characteristics are important in designing the economically optimum system.

\section{C.2.1.1 Electric Load Factor}

Technically, a power system can be designed for any load shape. However, a level load shape generally provides the best economic return and is better able to repay the fixed capital investment. Of course, the facility load shape is only the starting point. Even a low facility-load factor can have a CHP system with a high-load factor if the system capacity is matched to the base load portion of the facility's electric demand. However, if the proposed CHP system is sized so small as to provide only an insignificant 
portion of the total facility load, much less incentive exists for the facility owner to invest in CHP. If a system is sized above the minimum facility load, periods of load following will be necessary and agreements with the connecting utility to buy or transport the excess power may be needed. If a sales agreement is in place, the system is technically then a base load system operating full-time. If loadfollowing system is in place, the CHP technology chosen must be able to follow load easily and efficiently and may require frequent startups and shutdowns. CHP technologies differ in their ability to meet load-following requirements.

\section{C.2.1.2 Capacity Factor}

Capacity factor is similar to load factor, but it is measured on the output of the power system rather than on the overall facility demand. The capacity factor is a key indicator of how the capacity of the prime mover is used during operation. The capacity factor is a useful means of indicating the overall economics of the CHP system. The capacity factor indicates the facility's proximity to base load operation. Capacity factor is defined as follows:

$$
\text { Capacity Factor }=\frac{\text { Actual Energy Production }}{\text { Peak Capacity of Prime Mover x 8,760 hours }}
$$

A low capacity factor is indicative of peaking applications that derive economic benefits generally through the avoidance of high-demand charges. A high capacity factor is desirable for most CHP applications as it enables them to obtain the greatest economic benefit. A high capacity factor effectively reduces the fixed unit costs of the system $(\$ / \mathrm{kWh})$ and allows it to remain competitive with grid-supplied power.

\section{C.2.1.3 Thermal Demand and Load Factor}

Heat recovery is often the most important benefit when compared to buying electricity and fuel separately. The more heat that can be used, the better the economics of the system and the more positive the environmental impact. A high thermal load factor provides the best economic fit with a base load CHP system. High loads that are seasonal or noncoincident with the electric demand are not good loads for a CHP system.

\section{C.2.1.4 Power to Steam (P/S) Ratio}

The P/S ratio calculation is a good tool for screening CHP applications. CHP systems produce electricity and heat in a more-or-less fixed ratio. Depending on the technology, the inherent P/S ratios of CHP systems typically range from 0.6 to 1.5 depending on the technology. Therefore, facilities with P/S ratios in this range can use the full value of heat and electricity from an appropriately sized CHP system. Facilities with P/S ratios above 1.5 do not have adequate thermal demand to make full use of the waste heat produced. Such facilities are generally not good economic candidates for CHP. Of course, reducing the size of the CHP system to match the thermal load is possible. Facilities with P/S ratios below 0.6 have excess thermal load beyond what the CHP system can provide. Such facilities are still economic CHP candidates, but supplementary boiler capacity is required. An alternative that is sometimes available is to size the CHP system to the thermal load and to export power to the grid. CHP systems with electric sales contracts are common in the industrial sector. In some cases, the CHP system is a separate legal entity that dispatches power to the grid, and the industrial facility is simply the steam host. 


\section{C.2.1.5 Electric to Thermal Load Conversion}

Certain types of electric loads can be converted to thermal load to increase the use of thermal energy for the system or to provide a thermal load for a larger system. The most important of these convertible loads are cooling and refrigeration loads. The electrically driven vapor-compression cycles that are commonly used to meet these loads can be replaced with heat-actuated absorption or adsorption (desiccant) cycles. These cycles produce cooling or refrigeration in a chemical cycle that relies on the heat from hot water or steam as the primary input. The use of absorption or desiccant systems simultaneously reduces electric demand and increases thermal demand, creating a lower P/S ratio for more effective use of the electric and thermal energy from the CHP system. This approach is more commonly used in commercial applications where $\mathrm{P} / \mathrm{S}$ ratios are much higher and thermal load factors much lower. However, there are potentially useful applications in the food industry and in some chemical-processing industries.

\section{C.2.2 Quality of Recoverable Heat}

The thermal requirements of the end user may range from hot water to high-pressure steam. The quality of heat dictates the feasibility of a CHP system or the selection of the prime mover. Gas turbines offer the highest quality heat. Gas turbines reject heat almost exclusively in their exhaust gas stream. The high temperature of this exhaust can be used to generate high-pressure steam or lower-temperature applications such as low-pressure steam or hot water. Larger gas turbines (typically $>25 \mathrm{MW}$ ) are frequently used in combined cycles where high-pressure steam is produced in the HRSG and is used in a steam turbine to generate additional electricity. The high levels of oxygen present in the exhaust stream allow for supplemental fuel addition to generate additional steam at high efficiency.

Reciprocating engines typically have a higher efficiency than most gas turbines in the same output range and are good fits where the thermal load is low relative to electric demand. Reciprocating engines produce a lower grade of rejected heat. Heating applications that require low-pressure steam (15 psig) or hot water are most suitable, although the exhaust from a reciprocating engine can generate steam up to 100 psig.

\section{C.2.3 Reliability Needs}

Facilities with very high costs associated with power outages may have special requirements for the design of the CHP system. Most CHP systems provide power with reliability above $95 \%$. A system with $99 \%$ reliability though would still be expected to be down for $87 \mathrm{~h} /$ year. Some customers may demand higher reliability and cannot tolerate a single hour of outage per year. Typically, CHP systems use the reliability of the electric grid to increase the overall reliability of the power supply to the facility. The economics are improved by maximizing the reliability of the CHP system, thus minimizing the use of the utility grid as backup. Reliability can be increased by designing the CHP system with redundant units. Customers whose reliability requirements exceed the capability of the utility grid typically design uninterruptible power systems (UPS). These systems rely on batteries, back-up generators, and electronic devices.

\section{C.2.4 Power Quality}

The ability to control the voltage, current, frequency, harmonics, and power factor associated with electricity is called power quality. Utilities maintain high standards of power quality, and most customers do not need to consider additional measures. For some customers, such as silicon chip manufacturers, precise control of these factors is important to maintaining the quality of their product. Alternatively, some facilities have processes that create power quality disturbances in the grid such as low-power factor from high motor loads or flicker from the operation of an electric arc furnace. For both of these types of 
facilities, the selection of CHP system and ancillary equipment is important. For example, fuel cells produce DC power and rely on power electronics (inverter) to produce $60-\mathrm{Hz}$ power. This type of system has been demonstrated in high quality applications. Some facilities can also use a power system to control their power factor more economically thereby avoiding utility-imposed penalties or investment in nonproductive control equipment.

\section{C.2.5 Industrial Heat Recovery}

Industrial sites that produce excess heat or steam from a process may offer a CHP opportunity. If the excess thermal energy is continuously available or at a high-load factor and is of sufficient quality, this heat can be used in a "bottoming cycle" to generate electricity in a steam turbine. In addition to electrical generation, steam turbines are often used to drive rotating equipment such air compressors or refrigeration compressors. Through a variety of turbine designs, the steam exhausted from the turbine can be used for lower grade heating applications or cooling in a CHP configuration.

\section{C.2.6 Environmental Requirements}

Environmental requirements are generally a function of locality rather than a facility's product or process. The local or regional standards tied to federal requirements can determine, at a minimum, the type of environmental controls that are required on the system. In some tightly controlled areas, even the selection of the prime-mover technology is affected. Generation technologies differ in their inherent emissions and the degree to which emissions can be controlled within the process. They also differ in the use special exhaust clean-up technologies. Currently, environmental requirements are based on the selected technology. However, regulators may change these standards to an output-based approach that is technology neutral.

\section{C.2.7 Fuel Supply}

A potential system issue for gas turbines is the supply pressure of the natural gas distribution system at the end user's property line. Gas turbines need minimum gas pressures of about 120 psig for small turbines with substantially higher pressures needed for larger turbines. Assuming there is no highpressure gas service, the local gas-distribution company would have to construct a high-pressure gas line or the end user must purchase a gas compressor. The economics of constructing a new line must consider the volume of gas sales over the life of the project. Gas compressors may have reliability problems especially in the smaller size ranges. If "black start" capability is required, then a reciprocating engine may be needed to turn the gas compressor, adding cost and complexity.

Diesel engines should be considered where natural gas is not available or is very expensive; however, special permitting may be required for on-site fuel storage. Diesel engines have excellent part-load operating characteristics and high power densities. In most locations, environmental regulations have largely restricted their use for CHP.

\section{C.2.8 Noise}

Noise is a consideration in designing a CHP system. Engine and turbine installations are often installed in building enclosures to attenuate noise to surrounding communities. Special exhaust silencers or mufflers are typically required on exhaust stacks. Gas turbines, essentially a modified jet engine, require a high volume of combustion air, causing high velocities and associated noise. Inlet air filters can be fitted with silencers to substantially reduce noise levels. 
Gas turbines are more easily confined than reciprocating engines within a factory-supplied enclosure. Reciprocating engines require greater ventilation because of radiated heat that makes their installation in a sound-attenuating building often the most practical solution. Gas turbines require much less ventilation and can be concealed within a compact steel enclosure. 

ORNL/TM-2001/169

\section{INTERNAL DISTRIBUTION}

\author{
1. M. A. Brown \\ 2. P. W. Garland \\ 3. C. R. Hudson \\ 4-13. M. A. Karnitz \\ 14. M. Olszewski \\ 15. D. T. Rizy \\ 16. D. P. Stinson
}

\author{
17-36. T. K. Stovall \\ 37. T. J. Theiss \\ 38. A. L. Wright \\ 39. Central Research Library \\ 40-41. ORNL Laboratory Records-OSTI \\ 42. ORNL Laboratory Records-RC
}

\section{EXTERNAL DISTRIBUTION}

43. Richard Brent, Solar Turbines, 818 Connecticut Avenue, N.W., Suite 600, Washington, DC 20006

44. Chris Cockrill, Seattle Regional Office, U.S. Department of Energy, SRO, Kansas City, MO

45-94. Keith Davidson, 701 Palmar Airport Road, Suite 200, Carlsbad, CA 92009

95. Neal Elliott, Council for an Energy-Efficient Economy, 1001 Connecticut Ave., NW Ste. 801, Washington, DC 20036

96. Susan Freedman, Northeast-Midwest Institute, 218 D Street, SE, Washington, DC 20003

97. Joseph F. Galdo, Office of Distributed Resources, U.S. Department of Energy, EE-16, Washington, DC 20024

98-107. Bruce Hedman, Onsite Sycom Energy Corp, 1401 Wilson Blvd, Suite 1101, Arlington, VA 22209

108. Patricia A. Hoffman, Office of Distributed Resources, U.S. Department of Energy, EE-16, Washington, DC 20024

109. Susan Horgan, Distributed Utility Associates, 1062 Concannon Blvd., Livermore, CA 94550

110. Tina Kaarsberg, Deputy Assistant Secretary for Power, U.S. Department of Energy, EE-10, Washington, DC 20024

111. Skip Laitner, EPA Office of Atmospheric Programs, $5013^{\text {rd }}$ Street, NW., $4^{\text {th }}$ Floor, MS-6201, Washington, DC 20001

112. Brian Marchionini, Energetics, 501 School Street, S.W., Suite 440, Washington, DC 20024

113. William P. Parks, Deputy Assistant Secretary For Power, U.S. Department of Energy, EE-10, Washington, DC, 20024

114. Rich Scheer, Energetics, 501 School Street, S.W., Suite 440, Washington, DC 20024

115. Anna Monis Shipley, Research Associate, American Council for an Energy-Efficient Economy, 1001 Connecticut Ave, NW, Suite. 801, Washington, DC 20036

116. Merrill A. Smith, Office of Distributed Resources, U.S. Department of Energy, EE-16, Washington, DC 20024

117. Mark Spurr, Kattner/FVB District Energy, Inc. 150 South Fifth Street, Suite 340 Minneapolis, MN 55402

118. Denise Swink, Office of Industrial Technologies, U.S. Department of Energy, EE-20, Washington, DC 20024

119. Suzanne Watson, Northeast-Midwest Institute, 218 D Street, SE, Washington, DC 20003 